Pacific Northwest

National Laboratory

Operated by Battelle for the

U.S. Department of Energy

\section{National Incident Management System (NIMS) Standards Review Panel Workshop Summary Report}

$\begin{array}{ll}\text { RD Stenner } & \text { DS Schwartz } \\ \text { JL Kirk } & \text { KS Judd } \\ \text { JR Stanton } & \text { GM Gelston } \\ \text { P Shebell } & \end{array}$

February 2006

Prepared for the U.S. Department of Energy under Contract DE-AC05-76RL01830 


\title{
DISCLAIMER
}

This report was prepared as an account of work sponsored by an agency of the United States Government. Neither the United States Government nor any agency thereof, nor Battelle Memorial Institute, nor any of their employees, makes any warranty, express or implied, or assumes any legal liability or responsibility for the accuracy, completeness, or usefulness of any information, apparatus, product, or process disclosed, or represents that its use would not infringe privately owned rights. Reference herein to any specific commercial product, process, or service by trade name, trademark, manufacturer, or otherwise does not necessarily constitute or imply its endorsement, recommendation, or favoring by the United States Government or any agency thereof, or Battelle Memorial Institute. The views and opinions of authors expressed herein do not necessarily state or reflect those of the United States Government or any agency thereof.

\author{
PACIFIC NORTHWEST NATIONAL LABORATORY \\ operated by \\ BATTELLE \\ for the \\ UNITED STATES DEPARTMENT OF ENERGY \\ under Contract DE-AC05-76RL01830
}

Printed in the United States of America
Available to DOE and DOE contractors from the Office of Scientific and Technical Information,
P.O. Box 62, Oak Ridge, TN 37831-0062;
ph: (865) 576-8401
fax: $(865) 576-5728$
email: reports@adonis.osti.gov

\footnotetext{
Available to the public from the National Technical Information Service, U.S. Department of Commerce, 5285 Port Royal Rd., Springfield, VA 22161 ph: (800) 553-6847 fax: $(703) 605-6900$ email: orders@ntis.fedworld.gov online ordering: http://www.ntis.gov/ordering.htm
}

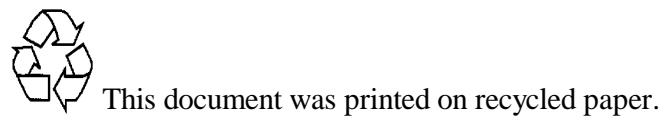




\title{
National Incident Management System (NIMS) Standards Review Panel Workshop Summary Report
}

\author{
R.D. Stenner D.S. Schwartz \\ J.L. Kirk K.S. Judd \\ J.R. Stanton G.M. Gelston \\ P. Shebell
}

February 2006

Prepared for

the U.S. Department of Homeland Security under U.S. Department of Energy

Contract DE-AC05-76RL01830

Pacific Northwest National Laboratory

Richland, Washington 99352 


\section{Executive Summary}

The need for developing a national incident management system as identified in the Homeland Security Act of 2002 was reinforced during the tragic events following Hurricane Katrina. U.S. Department of Homeland Security (DHS) Secretary Michael Chertoff in his October 4, 2005 letter to State Governors stated: "Hurricane Katrina was a stark reminder of how critical it is for our nation to approach incident management in a coordinated, consistent, and efficient manner. All levels of government must be able to come together to prevent, prepare for, respond to, and recover from any emergency or disaster. Operations must be seamless and based on common incident management doctrine, because the challenges we face as a nation are far greater than the capabilities of any one jurisdiction."

The National Incident Management System (NIMS) was introduced in March 2004, and is a framework for organizing response on a national scale. It requires use of the Incident Command System (ICS) and represents a core set of doctrine, principles, terminology, and organizational processes to enable effective, efficient, and collaborative incident management at all levels of response. NIMS is based on a balance between flexibility and standardization.

The NIMS Integration Center (NIC) is responsible for the ongoing management and maintenance of the NIMS and has the responsibility of identifying and evaluating national-level standards to support NIMS compliance and implementation. The Science and Technology Directorate of DHS used an existing contract with Pacific Northwest National Laboratory (PNNL) to provide technical assistance to the NIC to support the standards effort. PNNL was asked to identify, review, and develop key standards, when necessary, to support NIMS compliance and implementation. In August 2005, PNNL invited a panel of subject matter experts (SME) to Seattle, Washington for a one-day workshop on NIMS and standards. The panel was asked to assist in an initial review of a list of NIMS-related standards and to suggest other appropriate standards needed to fill gaps identified during the review process. In the workshop, the panel used the terms "strategic standards" and "tactical standards" for convenience and ease of discussion on the two types of standards. This report incorporates this concept of separating the standards into two types, but uses the terms "system standards" and "operational standards," respectively, as more inclusive terms for these two types of standards. The workshop included a pre-meeting information-gathering process and post workshop analysis of each of the standards the panel recommended.

The panel identified four standards for consideration. Three of these were characterized as systems standards and one as an operational type standard.

The three systems standards selected are:

- National Fire Protection Association (NFPA) 1561, Standard on Emergency Services Incident Management System

- $\quad$ NFPA 1600, Standard on Disaster/Emergency Management and Business Continuity Programs 
- American Society for Testing and Materials (ASTM) 2413-04/Hospital Emergency Incident Command System (HEICS), Standard Guide for Hospital Preparedness and Response/Hospital Emergency Incident Command System/Hospital Emergency Incident Command System.

The operational standard selected is:

- $\quad$ NPFA 472, Professional Competence of Responders to Hazardous Materials Incidents, when published in its revised form.

Most operational standards address a very broad range of tactical needs but are too detailed to be of much use for NIMS compliance and implementation. The panel suggested that the NIC issue formal guidance on the use of selected NIMS-related operational standards.

A comprehensive framework is needed that organizes NIMS-related standards to show the relationships that exist between standards and the relationship the standards have with components of the NIMS, i.e., command and management, preparedness, resource management, communication and information management, and supporting technology.

The PNNL team used the expertise of the SME panel to formulate a standards review process to be used in future standards review support to the NIC. The process is summarized below:

1) Refine and expand the search criteria for each NIMS component, working closely with the NIC to identify specific implementation needs

2) From existing listings of standards, identify other key nationally recognized standards that support additional NIMS compliance and implementation needs

3) Review the identified standards against the expanded criteria of Item 1 and select those standards that significantly address one or more of the criteria

4) Capture the sections(s) of the selected standard that specifically address the respective NIMS component criteria

5) Work with the Standards Portfolio to adopt the selected standard, which includes developing formalized Federal Emergency Management Agency (FEMA) guidance to the field that identifies the specific NIMS component(s) necessary for compliance and implementation needs addressed by the respective standard

6) Develop performance criteria from the captured material under Item 4 to help ensure compliance with the adopted standard

7) Finalize the implementation of the adopted standard by publishing the performance criteria.

The NIMS standards identification/development process may need to be incremental as the NIMS develops, focusing first on the strategic (systems)-level standards and later on the tactical (operations)level standards. Finally, the NIC may not want to incorporate or endorse the more prescriptive tactical standards associated with the internal operations of a response organizations. 


\section{Contents}

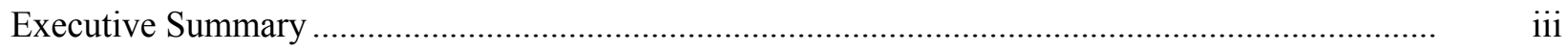

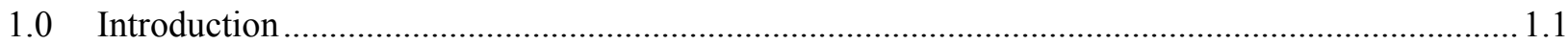

1.1 The National Incident Management System Document ......................................................... 1.1

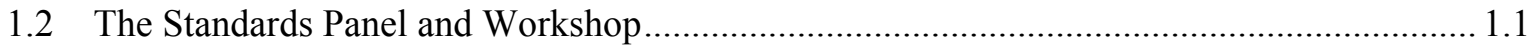

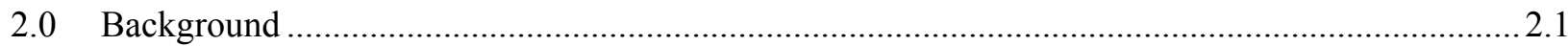

2.1 National Incident Management System, Department of Homeland Security,

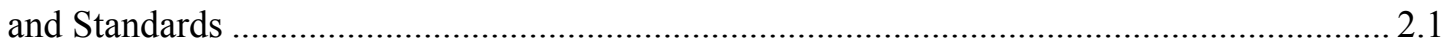

2.1.1 The National Incident Management System …...................................................... 2.1

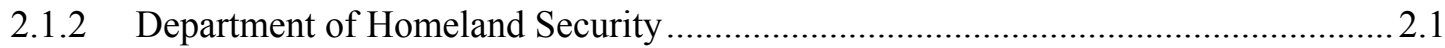

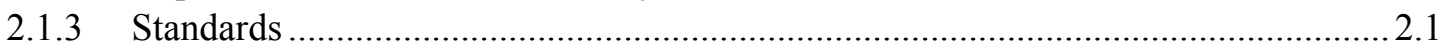

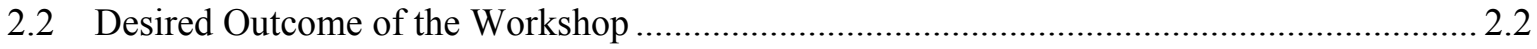

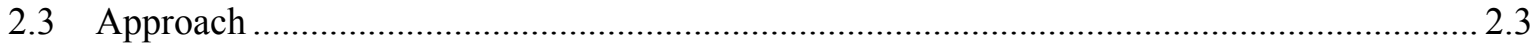

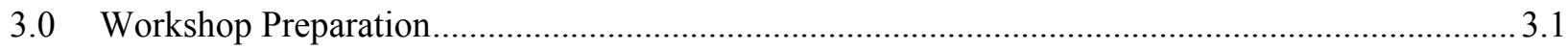

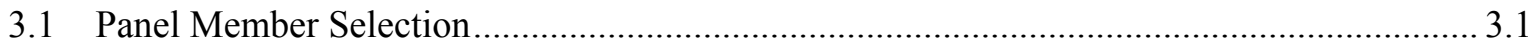

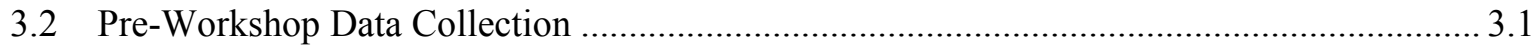

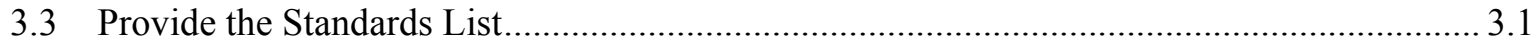

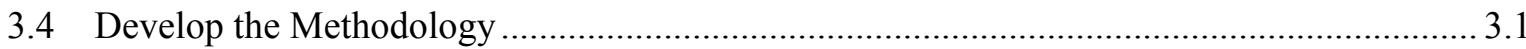

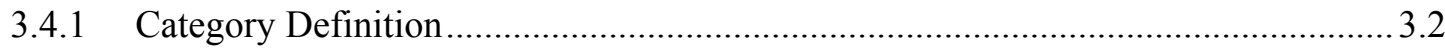

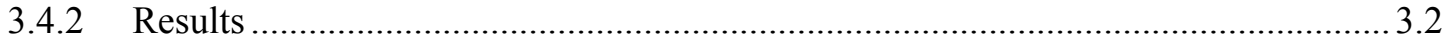

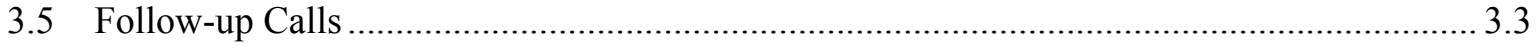

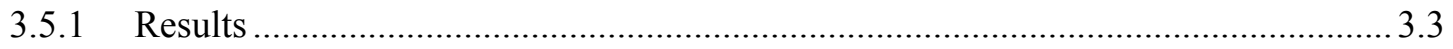

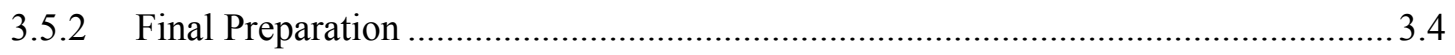

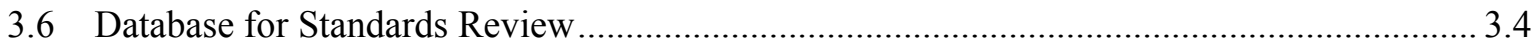

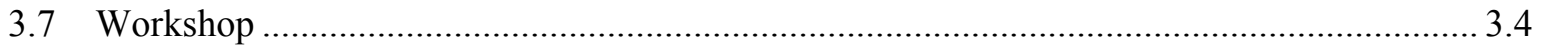

3.7.1 Definition of Standard as Used in the Workshop ................................................... 3.4

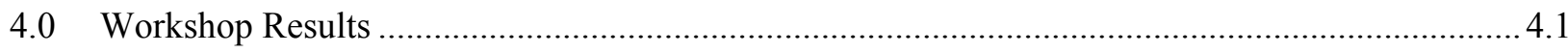

4.1 Critical Needs for Guidance/Standards ............................................................................. 4.1

4.1.1 What Does National Incident Management System Compliance Mean to You at the Local Level? ........................................................................................... 4.1

4.1.2 Is There a Need for More Specific Guidance to Local or State Jurisdictions to Effectively Implement a National Incident Management System? ........................... 4.1

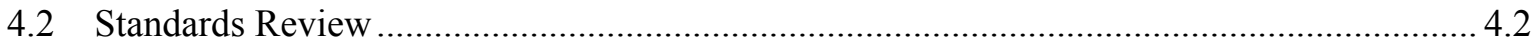

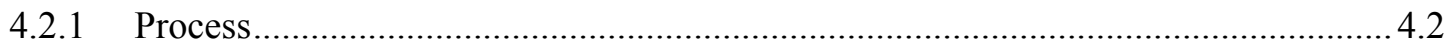

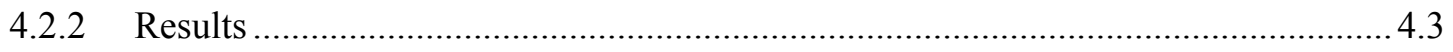

5.0 Rationale Used in the Workshop Decision Process ............................................................... 5.1

5.1 Criteria for National Incident Management System Compliance and Implementation.......... 5.1

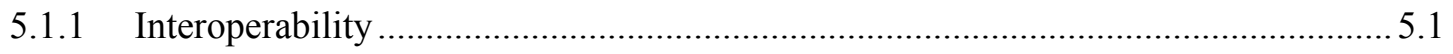




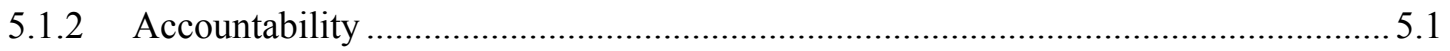

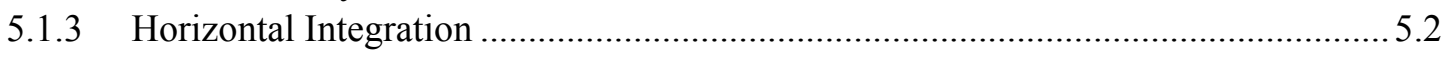

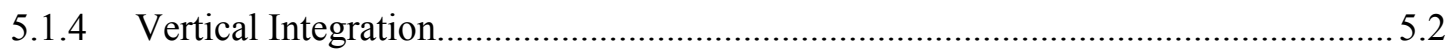

5.1.5 Resource Compatibility and Capacity ............................................................. 5.2

5.1.6 Consistency from Standards and Guidance for National Incident Management System

5.17 Risk-Based Preparedness

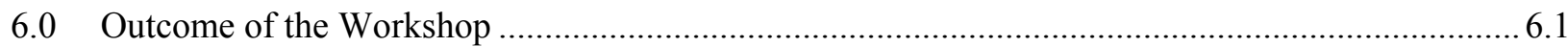

6.1 Two Categories of National Incident Management System - Related Standards ................. 6.1

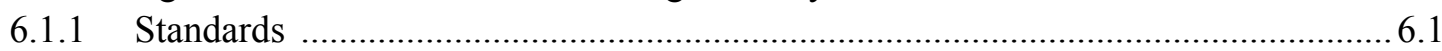

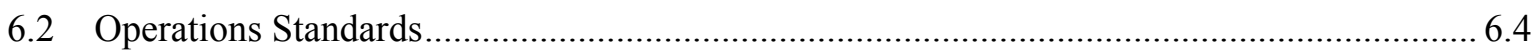

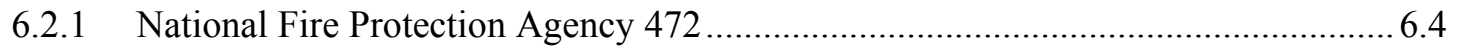

6.3 National Incident Management System and Incident Command System Integration ............ 6.5

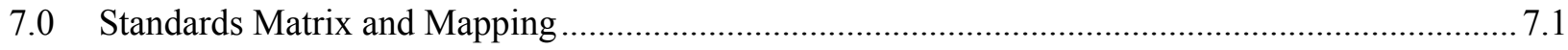

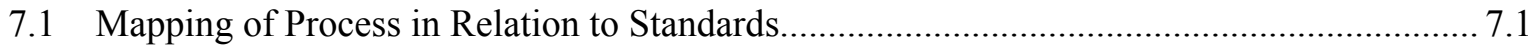

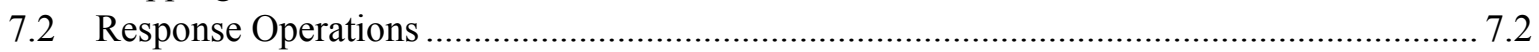

7.3 Matrix Tool and Matrix to Show Standards Application Status ......................................... 7.3

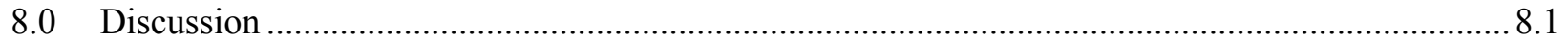

\section{Figures}

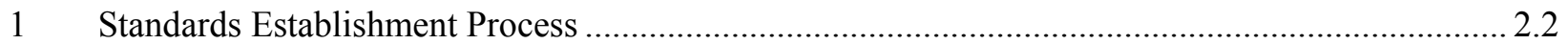

2 Example of NIMS Mapping to Response Operations ................................................................ 7.1

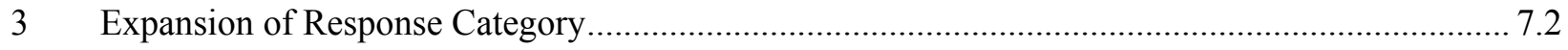

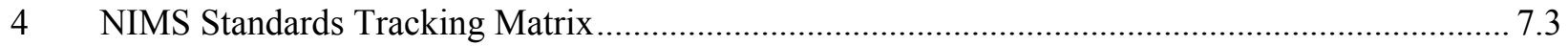




\section{Acronyms}

ASTM ASTM International (formerly known as the American Society for Testing and Materials)

DHS U.S. Department of Homeland Security

DOJ U.S. Department of Justice

EMAP Emergency Management Accreditation Program

EMS Emergency Medical Services

EPA U.S. Environmental Protection Agency

ESF Emergency Support Function

ESL Essential Standards List

FEMA Federal Emergency Management Agency

HAZMAT hazardous materials

HEICS Hospital Emergency Incident Command System

HSEEP Homeland Security Exercise Evaluation Program

ICS Incident Command System

IMS-WG Incident Management System Working Group

JACHO Joint Commission on the Accreditation of Healthcare Organizations

NEMA National Emergency Management Association

NENA National Emergency Number Association

NFPA National Fire Protection Association

NIC NIMS Integration Center

NIMS National Incident Management System

OSHA Occupational Safety and Health Administration

PNNL Pacific Northwest National Laboratory

SDOs standards development organizations

SME subject matter experts

TCL Target Capabilities List

WMD weapons of mass destruction 


\subsection{Introduction}

This report presents the standards review process used to identify and evaluate an initial set of National Incident Management System (NIMS)-related standards and concludes with a discussion of a generalized approach for further standards identification.

The importance and necessity for a fully developed and fully implemented NIMS was demonstrated by the impact of hurricanes that hit Florida in 2004, and most recently with Hurricane Katrina in 2005. Throughout the history of emergency response to major disasters, especially where multiple response organizations are involved, there have been systemic problems in the consistency and uniformity of response operations.

\subsection{The National Incident Management System Document}

The NIMS seeks to provide uniformity and consistency for incident management through the use of common terminology and protocols that will enable responders to operate in a coordinated manner to ensure an efficient response. In a recent statement to State Governors, U.S. Department of Homeland Security (DHS) Secretary Chertoff stated: "Hurricane Katrina was a stark reminder of how critical it is for our nation to approach incident management in a coordinated, consistent, and efficient manner." $\mathrm{He}$ further pointed out that "our [response] operations must be seamless and based on common incident management doctrine, because the challenges we face as a nation are far greater than capabilities of any one jurisdiction."

A primary objective of the NIMS is to provide an architecture or framework for organizing response on a national scale. It requires use of the Incident Command System (ICS) and represents a core set of doctrine, principles, terminology, and organizational processes that enables effective, efficient, and collaborative incident management at all levels.

The NIMS establishes the NIMS Integration Center (NIC) and gives it responsibility for ongoing management and maintenance of the NIMS document. It also gives the NIC responsibility for identifying, evaluating, and facilitating the development of national-level standards ${ }^{1}$ to support NIMS compliance and implementation. The NIC must ensure that the flexibility necessary for effective local response operations is maintained to address specific jurisdictional and geographical needs across the nation.

\subsection{The Standards Panel and Workshop}

The Science and Technology Directorate of DHS used an existing contract with Pacific Northwest National Laboratory (PNNL) to provide technical assistance to the NIC. PNNL was asked to identify, review, and develop (when necessary) key standards to support NIMS compliance and implementation. The PNNL team convened a panel of subject matter experts (SME) to assist in the initial review of a list

\footnotetext{
${ }^{1}$ A national-level standard is recognized, accepted, and implemented by all levels of government as well as the private sector and non-governmental organizations.
} 
of NIMS-related standards ${ }^{2}$ and to suggest appropriate standards to fill gaps identified during the review process. The PNNL team utilized the expertise of the SME panel ("the panel") to formulate a standards review process to be used in future standards review support to the NIC.

Each standard the panel identified is discussed in detail. Specific pros and cons are listed in Appendix E. The report includes information regarding workshop preparation, data collection, data evaluation, and:

- The panel's perspective on the first responder community's receptiveness to NIMS

- A discussion on the need for additional guidance to support NIMS implementation of each selected standard

- A process map that can be used to select future NIMS-related standards

- A matrix that evaluates the identified standards against the NIMS components and shows where gaps exist

- A recommendation for a generalized approach for further standards identification and review.

\footnotetext{
${ }^{2}$ NIMS-related standards refers to voluntary consensus standards in the area of interoperable communications, data, sample collection, geospatial information, equipment certification, resources typing, training and exercises, and authentication and security certification.
} 


\subsection{Background}

\subsection{National Incident Management System, Department of Homeland Security, and Standards}

\subsubsection{The National Incident Management System}

The NIC has the responsibility to facilitate the establishment of standards in a variety of areas pertaining to incident management; however, it does not have statutory authority to develop Federal standards or the responsibility or resources to establish a process or infrastructure to adopt private sector standards.

The NIC strategy for the development and promulgation of NIMS-related standards involves working with other components of DHS, other Federal agencies and departments, and State and local governments. The NIC also wants to establish an Essential Standards List (ESL) that would represent a set of the most significant national standards for the NIMS. One of the panel goals was to identify a few initial candidate standards for the ESL.

\subsubsection{Department of Homeland Security}

The Standards Portfolio is the DHS component responsible for standards. Its mission is to develop and coordinate the adoption of national standards and appropriate evaluation methods to meet the needs of the homeland security mission.

The Standards Portfolio has three management directives that establish DHS policy regarding the adoption and development of standards. They establish a DHS National Standards Program designed to assist in identifying, creating, and cataloging all standards necessary for the proper execution of DHS activities, which includes the NIMS.

\subsubsection{Standards}

The Standards Portfolio has developed an integrated standards adoption process and infrastructure that includes 19 standards working groups. One of the working groups, the Incident Management System Working Group (IMS-WG), was established specifically to address NIMS-related standards. It will gather, analyze, and maintain information on standards that support NIMS, especially as they enhance a Tribal, State, or local jurisdiction's ability to utilize DHS's resources when managing an incident of national significance.

Figure 1 shows the basic relationship between NIMS-related standards, the panel, the ESL, DHS Adoption, and NIMS compliance and implementation. 


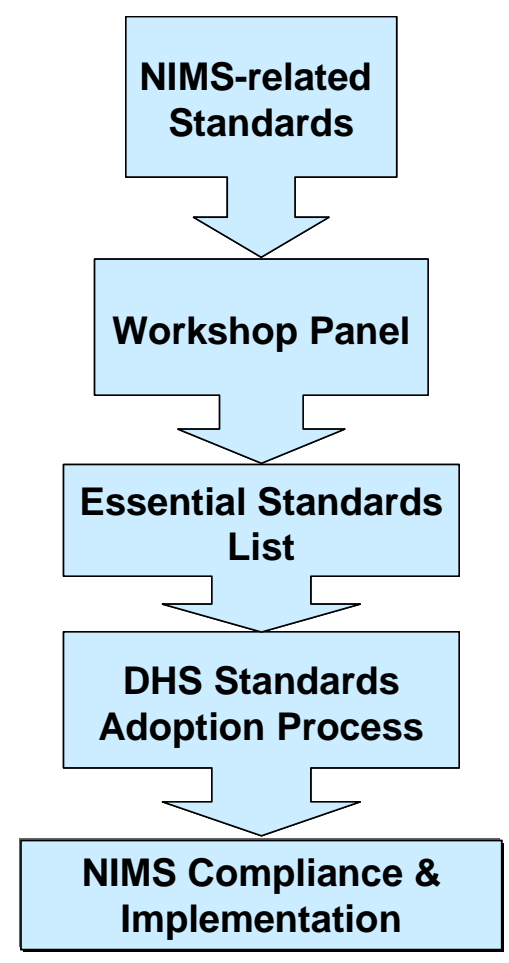

Figure 1. Standards Establishment Process

\subsection{Desired Outcome of the Workshop}

The workshop was designed to achieve four outcomes, each of which was presented to the panel at the outset of the workshop:

- Identification of critical need(s) for guidance to support NIMS compliance and implementation

- Identification of a small number of standards (5 to 8) considered essential to NIMS compliance and implementation; it is desirable that the standards selected represent a diversity of standards development organizations (SDOs)

- An understanding of why each standard was suggested and any criteria/conditions for its application to NIMS

- Identification of a strategy for identifying NIMS support standards.

Progress was made at the workshop toward each of these outcomes. The workshop approach was modified significantly in response to issues the panel raised during the first workshop session. This modification enabled the workshop to move forward and be quite productive. 


\subsection{Approach}

The following summarizes the steps used in the standards review process:

1) Establish the broad-based SME panel

2) Establish initial NIMS component categorization and search criteria from the NIMS and its support documents

3) Provide a list of NIMS-related standards, organized by the initial NIMS component criteria, to the panel

4) Develop a pre-workshop initial information collection and standards selection methodology to solicit one-on-one querying from each panel member

5) Conduct one-on-one telephone follow-up on the pre-workshop information individually submitted

6) Establish an interactive database management system to collect the pre-workshop information and to use it interactively in the workshop

7) Conduct the workshop

8) Formulate (in the workshop) the collective review criteria for the panel to use in selecting the few key standards

9) Facilitate the panel's review and selection of the suggested standards for NIMS compliance and implementation

10) Establish a small team to digest the proceedings and outcome of the workshop

11) Develop the workshop report. 


\subsection{Workshop Preparation}

\subsection{Panel Member Selection}

The panel was established to provide technical insight into possible compliance and implementation support standards for NIMS. Panel members were selected based on their subject matter expertise, organizational affiliation, and expected level of engagement in a workshop setting. SMEs were identified based on experience within Emergency Support Function (ESF) disciplines and standards areas as detailed in Appendix A. Individuals with broad experience and expertise were also selected to ensure all topics were adequately covered. Appendix B provides contact information for panel members and a list of PNNLTeam members. The process was as follows:

- Eight weeks before the workshop, PNNL identified several potential members for the panel and discussed the shortlist with the NIC

- Six weeks before the workshop, participation of the panel members was confirmed

- The project manager contacted each of the panel members to communicate the project objectives and responsibilities.

\subsection{Pre-Workshop Data Collection}

The NIC generated the list of NIMS-related standards for Step 3, which included standards identified by examining various agency websites, communicating with such agencies, and exploring various SDO standards lists.

The PNNL team was asked to help expedite this standards list effort by reviewing it and selecting a few key standards from this list that the NIC could use to begin developing an ESL for NIMS compliance and implementation. The concept of an ESL for NIMS is sound. It suggests keeping the list of standards identified to support NIMS compliance and implementation as small as possible while including standards that adequately and concisely address all of the respective NIMS components. The concept of an ESL for NIMS fits well with the outcome and suggested approach for future standards identification outlined in this report.

\subsection{Provide the Standards List}

Once the panel was finalized, introductory information with background and reference materials was sent to each panel member. The information included attachments such as a preliminary standards inventory, a more detailed NIMS standards compilation, which drew from a broader set of standards development organizations, and draft material from the NIC on possible State and local compliance activities.

\subsection{Develop the Methodology}

Each panel member was asked to:

- Conduct their review of the preliminary standards inventory using the provided template 
- Group each standard into one of the categories listed below

- Return the form for analysis two weeks before the workshop

For each standard, include their rationale for the category assigned and indicate which NIMS components (e.g., Command and Management Preparedness) the standard supported.

\subsubsection{Category Definition}

- Category A - Standard meets the following criteria for the ESL and should be considered for NIMS compliance guidance:

- The standard is applicable to one or more of the NIMS components

- The standard is essential to ensuring interoperability

- The standard can be practically implemented

- The standard does not conflict with an existing operating procedure or guidance that is well established and accepted.

- Category B - Standard is recognized and has a specific element or reference that may be applicable, but the entire standard is not applicable.

- Category $\mathrm{C}$ - Standard is not recognized. More information is needed to assess applicability.

- Category D - Standard is recognized and is not considered essential.

\subsubsection{Results}

A total of 11 individuals completed the template before the workshop convened, some of whom were unable to participate in the workshop.

The standards most frequently cited in Categories A and B, included:

- National Fire Protection Association (NFPA) 1600, Standard on Disaster/Emergency Management and Business Continuity Programs

- NFPA 1561, Standard on Emergency Services Incident Management Systems

- National Emergency Number Association (NENA)-01-002, Master Glossary of 9-1-1 Terminology

- Hospital Emergency Incident Command System (HEICS) III Hospital Emergency Incident Command System (1992)

- NFPA 472, Standard for Professional Competence of Responders to Hazardous Materials Incidents

- $\quad$ NFPA 1500, Fire Department Occupational Safety and Health Program

- $\quad$ NFPA 1001, Standard for Firefighter Professional Qualifications

- NFPA 1994, Standard for Protective Ensembles for Chemical/Biological Terrorism Incidents

- NFPA 1999, Standard on Protective Clothing for Emergency Medical Operations

- NFPA 1951, Standard on Protective Ensembles for USAR Operations. 
A complete summary of the categorization and corresponding rationale is summarized in Appendix C.

\subsection{Follow-up Calls}

Members of the PNNL Team conducted one-on-one telephone discussions with panel members after they completed the standards inventory template. The purpose of these discussions was to help the PNNL Team better understand the rationale behind standards assigned to Categories A and B.

The discussions included:

- The degree of ease or difficulty for the respondent to categorize the standards

- The standards/topic areas with which the respondents were most and least familiar

- Perceived gaps in standards development and what standards should be added to the list to address these gaps

- Any questions or concerns the panel member had about the process.

\subsubsection{Results}

The main observations from these pre-workshop discussions were:

- A few individuals thought that developing and grouping the standards inventory by NIMS component was a difficult task. Some thought:

o The template represented a good first attempt but it overemphasized fire-related standards

o There were gaps in other emergency responder disciplines

- Several individuals supported the idea that additional standards are needed to get all responders to operate under the incident command structure:

o One indicated that standards could provide the direction required to support NIMS compliance

o Another questioned the value of defining standards to assess NIMS compliance

- A few individuals considered the current NIMS training to be inadequate

- A few respondents noted there must be an awareness of laws and operating procedures that currently dictate how agencies respond to emergencies, and these need to be reconciled with the NIMS

Example: The National Contingency Plan establishes legal requirements for national and regional response teams and requires the U.S. Environmental Protection Agency (EPA) to use this system

- One respondent emphasized that many of the NFPA standards are not consistent with NIMS and indicated this must be addressed before standards are adopted for compliance

Example: A different resource typing is used in the NFPA standards than is used under other directives

- In general, standards must use common terminology, acronyms, and definitions. 


\subsubsection{Final Preparation}

As a concluding preparatory measure, the PNNL Team reviewed the standards categorized as A or B and preliminarily determined which of the 15 ESF disciplines applied to each standard. This was accomplished by initially reviewing the document summaries, table of contents, and index for keywords or concepts and then reviewing corresponding sections of the standard to determine whether the content aligned with one or more of the ESF categories.

\subsection{Database for Standards Review}

A NIMS standards review database was developed to collect all pre-workshop information and to be used as a decision making tool in the workshop. Appendix D provides details on the design and use of the database.

\subsection{Workshop}

On August 24, 2005, PNNL hosted the NIMS Standards Review Panel Workshop at the PNNL Battelle Seattle Research Center in Seattle, Washington. Sixteen panel members attended the workshop and used the above approach and data collected before and during the workshop.

\subsubsection{Definition of Standard as Used in the Workshop}

In the United States and international standards-setting communities, the term "standard" has a specific meaning. It refers to both the affirmative reasons for a given standard as well as the potential application of the respective standard. For purposes of this report, and to assist with communicating the intent of the panel's discussion to those authorities responsible for developing, directing, and implementing NIMS, the following working definitions are used:

- System Standards are standards oriented to identifying common processes used among various levels of government (Federal, State, Local and Tribal) and by non-governmental entities and the private sector. System standards have the over-arching purpose of identifying and describing essential activities organizations undertake that enable them to coordinate their separate functional activities, to integrate their activities with those of others, and that facilitate communication and understanding of actions taken, or to be taken, with other organizations. "System standards" may often be referred to as "process standards" or "strategic standards." Examples of system standards applications include communications networks, logistics, information systems, decision making processes, training and education requirements, and reporting systems.

- Operational Standards are standards oriented to describing specific activities, or operations, that personnel at various levels of government (Federal, State, Local and Tribal) and nongovernmental entities and the private sector may perform in preparing to execute or in executing specific tasks or assignments. Operational standards may often be referred to as "method standards" or "tactical standards." Examples of operational standards include certain hazardous materials (HAZMAT) response protocols, incident-scene management procedures, radio/communications discipline, incident-scene safety procedures, and certain field sampling techniques. 
Both system standards and operational standards may be stated in language that enables evaluation or judgment to be made about the degree to which the standard is actually being met, i.e., performance standards, or a standard being developed may be stated in such a way that progress toward meeting the standard may be measured. 


\subsection{Workshop Results}

\subsection{Critical Needs for Guidance/Standards}

The workshop began with a general discussion on critical needs for guidance and standards to support NIMS compliance and implementation. The intent of this open-ended discussion was to help identify priority areas for guidance within NIMS to help shape the subsequent discussion. The initial discussion centered around four questions posed by the facilitator, which are summarized below.

\subsubsection{What Does National Incident Management System compliance Mean to You at the Local Level?}

One participant interpreted NIMS compliance as "another bureaucratic process" imposed on the response community. Currently, checking the boxes does not ensure that people will understand the basic ICS principles. For example, the required ICS 700 series was not thought to cover the basics.

Concern was also expressed about the appropriateness of the term "compliance:"

- One participant describes NIMS as a philosophy or framework to guide governments, rather than a set of requirements for compliance

- NIMS is not yet sufficiently developed in areas beyond the ICS to specifically define some of the criteria for compliance

- Preparedness and communications were considered areas needing further development

- The NIC is really looking for "consistency" with NIMS rather than "compliance."

\subsubsection{Is There a Need for More Specific Guidance to Local or State Jurisdictions to Effectively Implement a National Incident Management System? If So, for What Topics/Components is the Need Greatest?}

Panel members generally considered it important that local and State jurisdictions receive more guidance on NIMS implementation:

- There was extensive discussion about whether that guidance should take the form of standards

- One person suggested that before standards are adopted, the focus should be on devices that enable people to work together effectively, such as protocols, systems, guidance documents, etc.

- Exercises, for example, were suggested as key to getting people to work together.

Several panel members commented on the need to ensure a common baseline understanding of NIMS and the ICS across the many disciplines and agencies involved (e.g., all responders should know what an Incident Action Plan is and what the various branches and sectors are):

- There is some risk to applying a "one size fits all" approach because communities are different they face different threats, have different jurisdictional hierarchies, have different resources, etc. all communities cannot be expected to be uniformly compliant with NIMS 
- Similarly, cultural differences across disciplines (e.g., fire, law enforcement) make uniformity difficult.

There was general support for the idea that NIMS compliance must be scalable and flexible, allowing communities that need to develop the opportunity to do so without being out of compliance with NIMS:

- Compliance should be attainable to all communities

- Communities should know what is required of them at different levels of compliance and where to go for support

- There was some discussion on what fundamentals or baseline elements would apply to communities across the nation.

One panel member specified an area where responders needed additional guidance, stating that responders struggle the most with type 3, 4 and 5 incidents - not major type 1 and 2 incidents:

- The panel member indicated there is currently no program for managing these types of incidents, yet they have the biggest impact on the community

- There is a need to define qualifications, plans, training, etc. to guide response in these incidents.

\subsection{Standards Review}

Using the data collected in the pre-workshop activities as a starting point, the panel selected five standards for detailed discussion as potential standards for the ESL. They were:

- NFPA 1561

- NFPA 1600

- NENA-01-002

- NFPA 472

- ASTM 2413-04/HEICS.

\subsubsection{Process}

Most of the workshop was focused on a systematic review of the standards identified by the panel using the following process:

- For each standard, panel members filled out a framework for analysis, which the group had developed during the morning discussion for use as a basis for comparing standards and assessing appropriateness for selection (see Appendix F: Framework for Analysis of Standards)

- Panel members then described the "pros" and "cons" associated with adopting the respective standard, using the framework as a guide

- Based on the review of pros and cons for each standard, participants elaborated on the "Conditions for Acceptance," which described what needed to be modified in the current standard if it were to be used for NIMS compliance and implementation. 


\section{Results}

The analysis framework and pros/cons/conditions summary for each standard reviewed by the panel are presented in Appendix E. 


\subsection{Rationale Used in the Workshop Decision Process}

\subsection{Criteria for National Incident Management System Compliance and Implementation}

The basic premises of NIMS compliance and implementation form the basis for the depth and breadth needed to be fully prepared to control and manage effectively the range of potential threats facing our nation. They are:

- Interoperability

- Accountability

- Horizontal integration of resources

- Vertical integration of resources

- Resource compatibility and capacity

- Consistency from standards and guidance for NIMS

- Risk-based preparedness.

The all-hazards preparedness approach is essential to being prepared for the full spectrum of both natural and intentional events.

\subsubsection{Interoperability}

Interoperability applies to all aspects and levels of incident management. For example, interoperable communications is absolutely essential for incident command to be successful, and it goes well beyond just the ability to effectively talk with each other, although that is critical. It also includes the ability to share information and data among all the various jurisdictional levels and technical disciplines working an incident. Interoperability of resources, which includes both personnel and equipment, is essential for effective incident command and becomes critical as an incident escalates in size and complexity. Interoperability of methods and approaches is essential for effective incident command and effective incident management. The incident commander must have confidence that the collective resources being used are compatible and synchronized.

\subsubsection{Accountability}

Responding units at all jurisdictional levels and all disciplines need to understand their mission and role at an event, and they need to be held accountable to perform that mission and role. The incident commander must have a clear understanding of these roles and accountability for effective incident management. Measures of accountability must be clear and understood by all affected parties, and these measures need to be tested and refined in joint preparedness planning and exercise. 


\subsubsection{Horizontal Integration}

Horizontal integration refers to the ability of responders to adequately integrate and coordinate themselves to work effectively through mutual aid agreements and integrated preparedness planning and exercise. When various jurisdictional units respond through mutual aid agreements to help each other, as an incident builds, both the incident commander and personnel in the responding teams need to understand each other's capabilities, strengths, weaknesses, and uniqueness. They need to be able to communicate with each other and use the collective resources effectively (i.e., be interoperable).

\subsubsection{Vertical Integration}

Vertical integration refers to the ability of responders acting under the authority of different levels of government, e.g., Federal, Tribal, State, and local, to adequately integrate themselves and effectively work together as an incident builds. The integration of incident command and unified command need to be well understood and seamless. There must be clear understanding of each others capabilities, strengths, weaknesses, and uniqueness. Effective interoperable communications and operations is critical for effective incident management.

\subsubsection{Resource Compatibility and Capacity}

The larger and more complex an incident becomes, the greater the need for resource compatibility and capacity because the resources of initial responder units become depleted. There is a greater need for responder units to share equipment. Thus, compatibility of equipment of individual responder units becomes essential. It must be clear when and where backup resources will be available to ensure adequate, continuous capacity of resources for the long-term response. Providing backup resources needs to be timely and in the control of incident/unified command so response operations are seamless.

\subsubsection{Consistency from Standards and Guidance for National Incident Management System}

Guidance from standards on NIMS compliance must be consistent at both the vertical and horizontal levels. It also must be flexible enough not to interfere with unique local response needs but consistent enough for local response units to effectively integrate with responders from all levels to make up an effective, unified response team for large and escalating events. There has been considerable debate as to whether the desired outcome for adopted NIMS standards should focus more on consistency or on compliance. A focus on consistency would make it harder to develop performance measures that ensure all the responder levels are effectively applying the standards and are adequate for vertical integration when needed, but would make it easier to ensure tailoring of response capabilities to meet unique everyday local response needs. A focus on compliance would make it easier to develop performance measures that ensure all the responder levels are effectively applying the standards and are well aligned for vertical integration when needed; however, force-fitting local response organizations will be painful and meet resistance.

\subsubsection{Risk-Based Preparedness}

In emergency preparedness, it is important to understand the risks associated with the scenarios and events that form the basis for the emergency preparedness and planning. To understand the risks, one 
must balance both the consequence associated with the scenario or event of consideration and the likelihood of its occurrence. Emergency preparedness planning will range from approaches to routine, small events, where the likelihood of occurrence is very high and the consequence to the community very low, to the more catastrophic events, where the likelihood of occurrence is fairly low but the consequence would be very high. Balancing the likelihood and consequence for the different scenarios will vary considerably among local jurisdictions across the country. NIMS standardized guidance must be flexible enough to allow for this variation. In areas where natural disasters occur often, uniqueness of response capability for such disaster must be accommodated. Likewise, areas of much higher risk of terrorist attack must allow equal accommodation. However, care must be taken to adequately prepare the nation to respond to high-consequence incidents in areas where its likelihood of occurrence is considered low. This is a huge challenge facing the nation, which is compounded by questions of cost versus costeffectiveness of expenditures necessary to be fully prepared. 


\subsection{Outcome of the Workshop}

\subsection{Two Categories of National Incident Management System - Related Standards}

In the workshop, the panel tended to divide the standards being discussed into either strategic or tactical as follows:

- The strategic standards were placed into a general category called "Systems Standards"

- The tactical standards were placed into a general category called "Operational Standards."

Most of the standards produced by the various SDOs developing emergency response-related standards tend to fall into the Operational Standards category. Only a few standards can be related to strategic NIMS needs in the Systems Category. The panel thought that initially the NIC is more in need of systems type standards and thus focused on selecting and reviewing those few existing standards they considered systems type standards. One widely recognized operational type standard (i.e., tactical standard) was also chosen for the NIC to consider as an example of a good tactical type standard.

\subsubsection{Standards}

The four systems type standards (i.e., strategic standards) the panel selected for more in-depth review and consideration by the NIC were:

- NFPA 1561

- NFPA 1600

- NENA-01-002

- $\quad$ ASTM 2413-04/HEICS.

While these standards are system type standards, they were written with a focus other than NIMS compliance and implementation. Thus, in the adoption process, the panel suggests that the NIC provide formalized Federal Emergency Management Agency (FEMA) guidance to the field regarding the specific aspects of each standard to be adopted, which identifies the components of that standard they believe are important for NIMS compliance and implementation. This would help first-responders in the field know exactly what was expected of them regarding that particular standard and solve the problem of generic systems standards (i.e., standards written for purposes other than NIMS compliance) including requirements that are either unnecessary and/or inappropriate for NIMS compliance and implementation.

\subsubsection{National Fire Protection Association 1561}

The panel felt that the NFPA 1561 standard supported the following NIMS components: Command and Management, Preparedness, Resource Management, Communication and Information Management, and Ongoing Management and Maintenance. They believed the standard applied to both people and process involved in first-response. It was felt that this standard was consistent with NIMS and had broad 
application across all disciplines. It helps define implementation at the local level and provides an organizational roadmap.

The panel identified the following issues in the standard that the NIC should specifically address in the FEMA field guidance. Some states, municipalities, and counties have not endorsed this standard for various reasons. The single unit ambulance addressed in the standard is not really ICS, where it was thought that ICS should apply at all levels. The language was written for the fire discipline and may require interpretation for other disciplines. Since NFPA wrote the standard, it may have to overcome a little fire department political stigma. It was believed that "law enforcement" may need the most interpretation and attention to make it acceptable to them. However, it was pointed out that no SDO is universally considered neutral across all disciplines. Finally, the standard was written for local governments so it may need some interpretation for State- and Federal-level organizations.

The panel suggested the following conditions for selection:

- Touch base with the NFPA committee currently revising NFPA 1561 (Note: this has been an ongoing activity of the NIC since mid-2005)

- Ensure the standard can be conformed with qualifications and training standards

- Consider compliance burdens to State, County, regions, and cities when adopting

- Address the issue of political acceptability across all government levels and disciplines, as it applies to NIMS compliance and implementation

- Endorse rather than enforce the standard, if possible (following the approach of the U.S. Department of Justice [DOJ])

- Before adopting, vet the guidance and standard more broadly with State and local organizations across the country

- Ensure consistent use of the standard at all levels (i.e., Federal, State, and local).

\subsubsection{National Fire Protection Association 1600}

The panel felt that the NFPA 1600 standard supported the following NIMS components: Command and Management (i.e., incident command structure, multi-agency coordination systems, and public information system), Preparedness (i.e., planning, training, exercises, personnel qualifications and certification, and mutual aid), Resource Management, and Ongoing Management and Maintenance. They believed the standard was most relevant to emergency management and government administrators and that it addressed process. The panel pointed out that they believed this standard to be widely used by the Emergency Management Accreditation Program (EMAP), adopted by the National Emergency Management Association (NEMA), and was generally endorsed by FEMA. They also felt that this standard was scalable.

The panel identified the following issues in the standard that the NIC should specifically address in the FEMA field guidance. The standard will likely have acceptance issues with disciplines other than fire (i.e., some of the same concerns as expressed for NFPA1561, but probably to a lesser extent). Adoption of this standard may raise the need for jurisdictions to confront new legislation (e.g., land use and zoning) and associated liability issues. It also would require the engagement of emergency management in these legislative issues. The standard requires risk assessment, which is quite technical and many jurisdictions 
will not have the in-house capability to conduct. Implementation issues for the private sector should be addressed (e.g., utilities are fairly well-aligned, but there is not necessarily a relationship between utilities and local governments). A concern was also expressed that local emergency managers may not have the ability and/or capacity to fully implement the standard. The panel suggested the following selection criteria:

- Requires an interagency, regularly revised planning process tied to a training and exercise program

- Needs a phased implementation and compliance approach

- Requires resources sufficient for capability and capacity building at all applicable levels

- Implementation requires cooperation between public and private sectors, with the onus on the public sector, which may need awareness and assistance.

\subsubsection{National Emergency Number Association-01-002}

The NENA standard is a master glossary of 9-1-1 terminology. Thus, it is suggested for consideration only if the NIC is looking for a good source of standard terminology for 9-1-1 type operations. The standard potentially provides a good perspective on handling an initial response. It sets standards for position location language. However, the panel was not sure that 9-1-1 organizations have been identified as responder organizations. It was thought that the NIC should probably draw terminology needs from this document rather than have it formally adopted.

\subsubsection{American Society for Testing and Materials 2413-04/HEICS (Standard Guide for Hospital Preparedness and Response/Hospital Emergency Incident Command System)}

The panel felt that the ASTM 2413-04/HEICS combination (i.e., HEICS is not a standard per se, but is called out in ASTM 2413-04) supported the following NIMS components: Command and Management, Preparedness, Resource Management (i.e., capacity management), and Ongoing Management and Maintenance (i.e., training and retraining). It directly supports the emergency medicine, health and hospitals, and mental health (others) relevant disciplines. This standard is a systems type standard (i.e., strategic), but also has some operations type (i.e., tactical) components incorporated into it. The standard applies to both people and process. The panel felt this standard combination provided an example of another discipline's (i.e., other than fire) ability to address incident command. It was believed that the Joint Commission on the Accreditation of Healthcare Organizations (JACHO) had strategic input into the standard through a representative on the ASTM task group preparing the standard, which helps in establishing its acceptability. The HEICS has been applied and implemented nationwide. A concerted effort was made in developing the ASTM standard to ensure consistency with the Occupational Safety and Health Administration (OSHA) first receiver's guidance document. OSHA also had representation on the ASTM task group preparing the standard. Through this standard, the HEICS incorporation provides a defined set of functions (i.e., job action sheets).

The panel identified the following issues in the standard that the NIC should specifically address in the FEMA field guidance. ASTM 2413-04 is new, making it difficult to test its broad use and acceptability. The HEICS guidance is for hospital facilities, which would need some modification to be applicable to other health-related disciplines such as public health and emergency medical services 
(EMS)-type first receivers. Although it addresses incident command, it was not written to specifically address the NIMS ICS model.

The panel suggested the following adoption criteria:

- Language in the standard will need to be confirmed to align directly with NIMS language or guidance provided to clarify

- NIMS implementation would need to be flexible enough to accommodate the HEICS functions and job descriptions

Jurisdictions within a hospital will need to specifically address their planning process (i.e., how the hospital(s) is(are) implementing HEICS).

\subsection{Operations Standards}

A host of operations type standards exist from several SDOs that have potential application to the tactical aspects of NIMS. The panel selected the NFPA 472 Professional Competence of Responders to Hazardous Materials Incidents Standard as an example of such an operations type standard that the NIC should consider as an operations (tactical) standard that supports NIMS compliance and implementation. It is important to point out that the NFPA 472 is in the process of undergoing a major revision to make it more universally applicable to all disciplines involved in a response to hazardous materials/weapons of mass destruction (WMD) incidents. Thus, the NIC should consider the new revised NFPA 472 standard.

While these operational standards are many and address a very broad range of tactical needs, they were also written with a focus other than NIMS compliance and implementation. Thus, the panel suggests the NIC provide formalized FEMA guidance to the field regarding the specific aspects of each of the operations type standards to be adopted that identifies the components of that standard they believe are important for NIMS compliance and implementation.

\subsubsection{National Fire Protection Agency 472}

The panel felt that the NFPA 472 standard (revised version) supported the following NIMS components: Preparedness (i.e., training) and Resource Management (i.e., credentialing). They believed the standard was most relevant to all disciplines who have responsibility for hazardous material/WMD response (i.e., fire service, emergency medical service, HAZMAT, law enforcement - mission dependent, emergency management - mission dependent, public works, public health - mission dependent, environmental, urban search and rescue, and coroner/medical examiner). The panel felt this standard dictates the knowledge, skills, and abilities of the individuals to safely and effectively respond to hazardous materials/WMD events. The standard, as it is being revised, is intended to have a multidisciplinary focus. The current standard, as will be the revised standard, is well accepted by fire and hazardous material response teams and Federal law enforcement. The standard has specific curricula associated with it. It has been accepted and accredited in many States. The standard makes HAZMAT response protocols more explicit than does 29CFR1910.120. The panel believes that standards like this NFPA 472 standard that pertain to basic capacity can enhance the capabilities of the community more than standards that cause them to pursue specialized, narrow capabilities. Thus, the panel believes NFPA 472 is a healthy standard and represents the host of good operations type standards the NIC should consider. It was not clear to the panel whether the NIC would want to begin focusing on these 
operational type standards in parallel with the systems type standards or first focus on the NIMS-related systems standards and then work on these operations type standards. The panel could see advantages and disadvantages to either approach. The question is one of timing.

The panel identified the following issues in the NFPA 472 standard that the NIC should specifically address in the FEMA field guidance. This standard also has associated with it some of the same acceptability barriers as noted in the respective systems standards discussions. However, the NFPA is purposely making the new NFPA 472 align better for all disciplines and will be working hard to overcome some of the past acceptability barriers. This standard is quite specific in its requirements, which could burden future standards with this degree of specificity.

The panel suggested the following selection criteria:

- Coordination with other DHS efforts and working groups (e.g., credentialing) is essential in adopting this standard

- The NIC needs to clarify the level of NIMS credentialing responsibilities and professional qualifications they want to address.

\subsection{National Incident Management System and Incident Command System Integration}

The NIMS is an architecture for organizing response on a national level. It uses ICS as the foundation of the command and management structure. In a paper published on the NIMS Website ${ }^{3}$, the following statements were made: "NIMS represents a core set of doctrine, principles, terminology, and organizational processes to enable effective, efficient and collaborative incident management at all levels. To provide the framework for interoperability and compatibility, the NIMS is based on a balance between flexibility and standardization." This paper further states that: "we need not approach ICS with the same mathematical precision used by an engineer. We are changing the culture of organizations and first responders at all levels of government. As long as implementation of ICS is consistent with the basic principles expressed in the NIMS, we will have made significant progress."

Ensuring consistent application of ICS across the nation is one of the first key responsibilities facing the NIC. The need for this was clearly demonstrated in the Hurricane Katrina event. Given the above statements, the focus for consistent NIMS ICS compliance should be on the six major required functions: command, operations, planning, logistics, finance and administration, and intelligence. Five of these major functions are well established nationally. It would seem reasonable to either find standards that address these functions and could be adopted or find guidance that could be used to develop uniform standards for these functions. The DOJ and other such agencies are likely to have either standards that could be qualified and adopted for the intelligence function, or guidance for which a uniform standard for the intelligence function could be developed.

\footnotetext{
${ }^{3} \mathrm{http}: / /$ www.fema.gov/txt/nims/nims_ics_position_paper.txt
} 


\subsection{Standards Matrix and Mapping}

\subsection{Mapping of Process in Relation to Standards}

Figure 2 maps the process through which NIMS relates to response operations and how standards are ultimately derived through a cascading process beginning with national level guidance and direction. Policy and doctrine provided by the NIMS, the National Response Plan and the National Contingency Plan are implementations of NIMS policy and doctrine by the Federal government. State and local jurisdictions have Emergency Operations Plans that may mirror the NRP/NCP, but they are not required, at this time. All-hazards event response can be divided into four areas: response operations, security, medical care, and management. Each of these is impacted by the extent to which there is advance notice of the event or it occurs without warning. Figure 2 depicts several of the subdivisions normally included in the "response operations" quadrant and how these become factors in the development of NIMS standards. Each of the subdivisions is then addressed in one of the NIMS Standards Categories. In addition, the subdivisions provide candidates for capability and performance measurement using the Target Capabilities List (TCL) and the Homeland Security Exercise Evaluation Program (HSEEP) criteria.

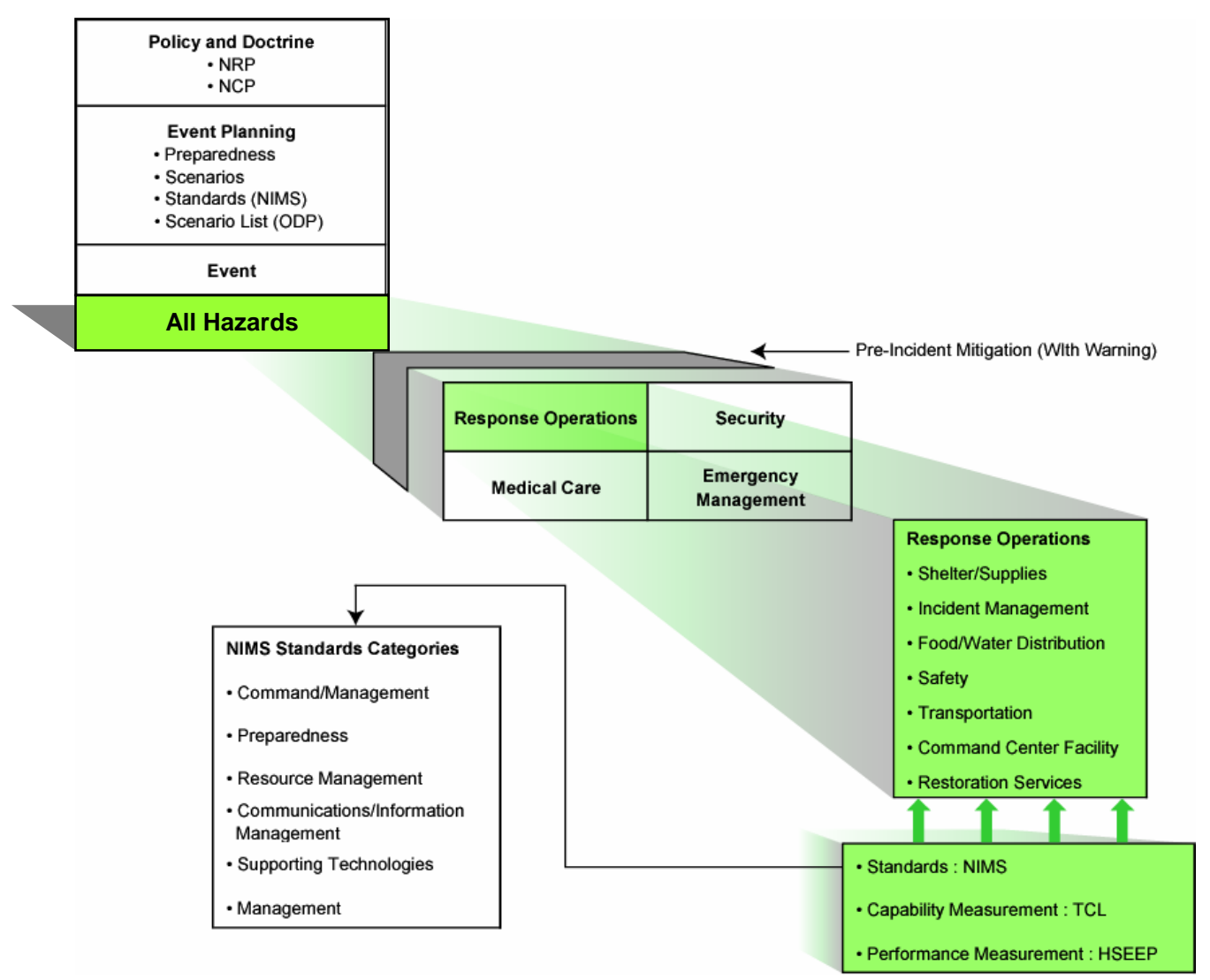

Figure 2. Example of NIMS Mapping to Response Operations 


\subsection{Response Operations}

Figure 3 expands on the previous chart (Figure 2) by displaying subdivisions in each of the four response categories. The subdivisions are not all-inclusive. Through the arrows in the center of the quadrant, the chart emphasizes that each of the areas, while shown separately, are interrelated. At the left of the quadrant is a reference to the need for qualifications and credentials for each of the functions presented. The right margin depicts the relationship between operations, support and planning. As the chart indicates, communications, interoperability, equipment, and a means of informing the public (media) provide the necessary supporting basis upon which to conduct successful operations in each of the four quadrants. To prepare for an event, effective planning, training and exercising that will provide the necessary skills and experience for response operations are essential.

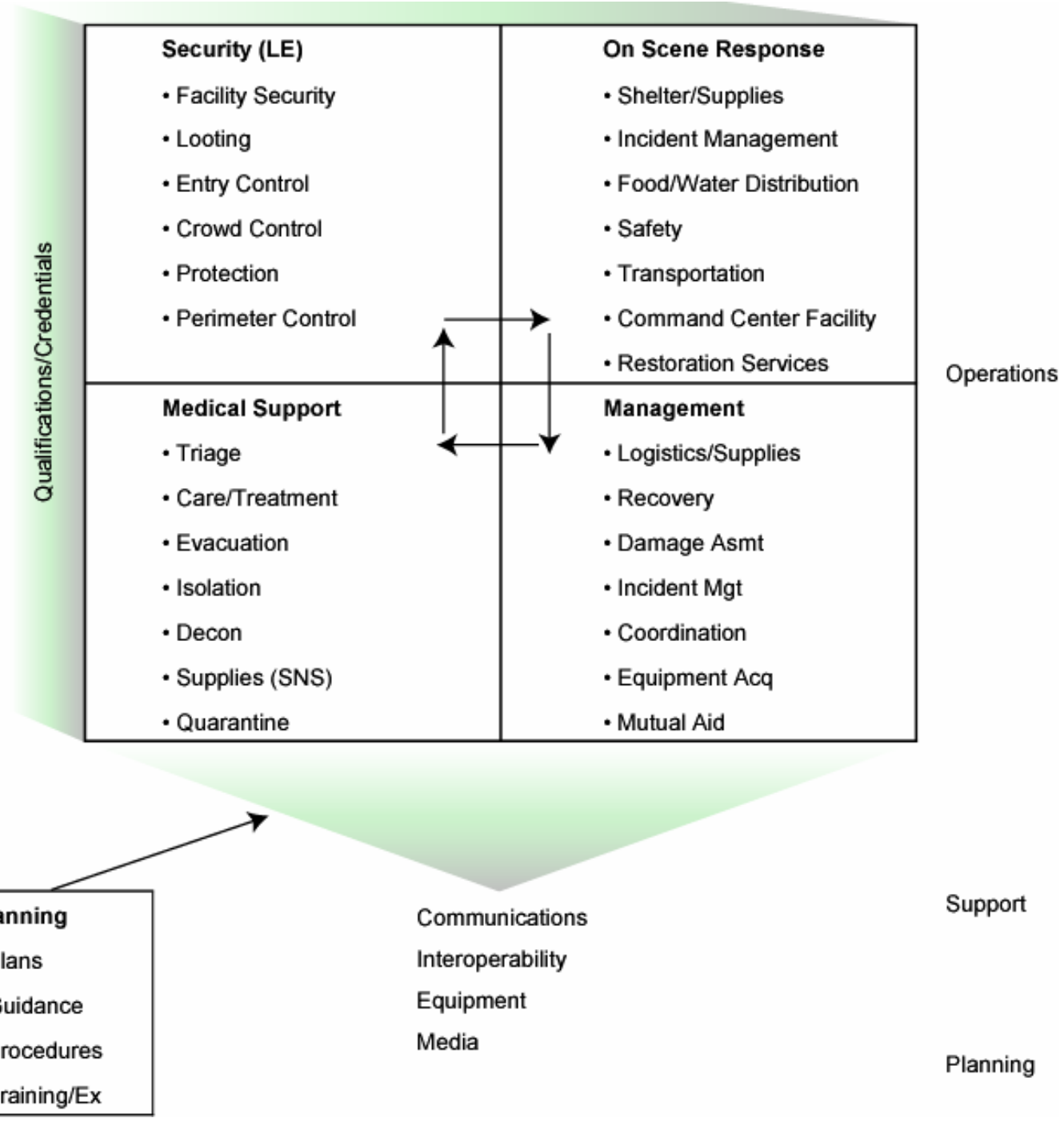

Figure 3. Expansion of Response Category 


\subsection{Matrix Tool and Matrix to Show Standards Application Status}

Figure 4 displays the status of the NIMS standards development process. The horizontal headings show several standards the workshop panel recommended as most applicable to incident management. The vertical list consists of the six NIMS Categories. Included in the vertical and horizontal array is the extent to which each of the recommended standards addresses one or more subdivisions within each of the NIMS Categories. The bars are an estimate of the degree to which the standard satisfies the requirements of a given NIMS component. The chart represents an initial attempt and will require further development. It does, however, provide a means of assessing the progress of the NIMS standards development process.

\begin{tabular}{|c|c|c|c|c|c|c|c|c|c|c|}
\hline \multirow{2}{*}{ NIMS Strategies Category } & \multicolumn{2}{|c|}{ NFPA 1600} & \multicolumn{2}{|c|}{ NFPA 1561} & \multicolumn{2}{|c|}{ NFPA 472} & \multicolumn{2}{|c|}{ HEICS/ASTM } & \multicolumn{2}{|c|}{ NENA-01-002 } \\
\hline & CBRNE & NAT & CBRNE & NAT & CBRNE & NAT & CBRNE & NAT & CBRNE & NAT \\
\hline \multicolumn{11}{|l|}{ Command and Management } \\
\hline \multicolumn{11}{|l|}{ Preparedness } \\
\hline \multicolumn{11}{|l|}{ Resource Management } \\
\hline \multicolumn{11}{|l|}{$\begin{array}{l}\text { Communications and } \\
\text { Information Management }\end{array}$} \\
\hline \multicolumn{11}{|l|}{ Supporting Technologies } \\
\hline $\begin{array}{l}\text { Ongoing Management and } \\
\text { Mainenance }\end{array}$ & & & & & & & & & & \\
\hline
\end{tabular}

Figure 4. NIMS Standards Tracking Matrix. The matrix organization represents the extent to which identified standards fulfill the requirement for a NIMS Category. Figure does not represent the complete review. The standards review tool will be applied later. 


\subsection{Discussion}

The theoretical mapping of the all hazards - response operations (Figure 4) is an example of how NIMS relates to response operations and how standards are ultimately derived through a cascading process beginning with national-level guidance and direction. Each of the response areas can be consistently mapped like the response operations. Likewise, the simple matrix form in Figure 4 can be used to display and track the status of the standards development process in support of NIMS compliance and implementation. Such a matrix can be developed over time as potential NIMS compliance and implementation standards are reviewed, selected, and adopted (with specific NIC guidance on their use). Thus, it provides a means to continuously track the NIMS compliance and implementation standards adopted with respect to the specific NIMS component(s) they support. Such a matrix will also show gaps for which new NIMS support standards need to be developed.

The work identified in this report focused on identifying only a few key standards to support NIMS compliance and implementation. A secondary, but equally important, focus was to establish a review process that can serve as a framework for the identification and comparison of future standards that may be candidates the NIC may consider for the ESL. Of particular importance are standards that may be needed for other disciplines not addressed in the four suggested standards. Examples of additional standards needed include those that specifically address law enforcement, EMS, logistics, communications, planning, etc. The following approach is suggested for identifying such standards:

1) Refine and expand the search criteria for each NIMS component, working closely with the NIC to identify specific compliance and implementation needs

2) From existing listings of potential applicable standards extracted from SDO database searches, identify other key nationally recognized standards that support these additional NIMS compliance and implementation needs

3) Review the identified standards against the expanded criteria of Item 1, and select those standards that significantly address one or more of the criteria

4) Capture the sections(s) of the selected standard that specifically address the respective NIMS component criteria

5) Work with the Standards Portfolio to adopt the selected standard, which includes developing formalized FEMA guidance to the field that identifies the specific NIMS component(s) necessary for compliance needs addressed in the respective standard

6) Develop performance criteria from the captured material under Item 4 to be used by the NIC to ensure compliance with the adopted standard

7) Finalize the implementation of the adopted standard by publishing the performance criteria. 


\section{Appendix A}

Review Panel Member Selection 


\section{Appendix A - Review Panel Member Selection}

Table A.1. Panel Members

\begin{tabular}{|c|c|c|c|c|c|c|c|c|c|c|c|c|c|c|c|c|c|}
\hline \multirow[b]{2}{*}{ Participant } & \multirow[b]{2}{*}{ Organization } & \multirow[b]{2}{*}{$\begin{array}{l}\text { Fed / } \\
\text { State / } \\
\text { Local / } \\
\text { Other }\end{array}$} & \multicolumn{15}{|c|}{ ESF Disciplines } \\
\hline & & & 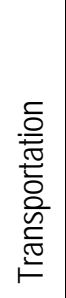 & 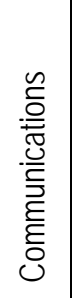 & 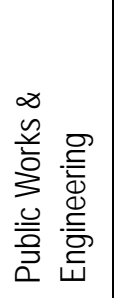 & 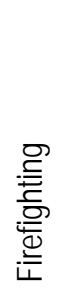 & 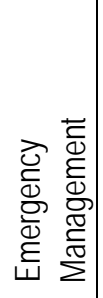 & 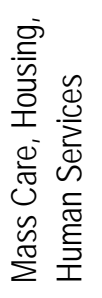 & 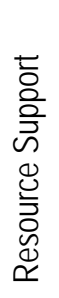 & 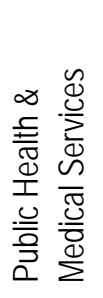 & 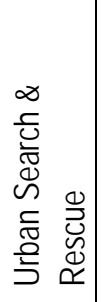 & 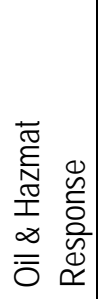 & 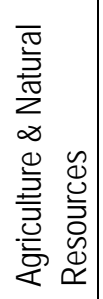 & $\begin{array}{l}\frac{\partial}{\bar{\omega}} \\
\text { फे }\end{array}$ & 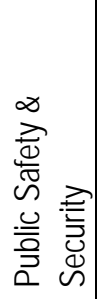 & 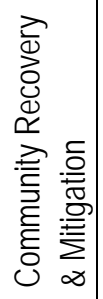 & 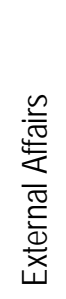 \\
\hline Don Olsen & $\begin{array}{l}\text { Hammer Facility (retired)/ Fire } \\
\text { and IC Consultant for Regional } \\
\text { Technology Integration Initiative }\end{array}$ & F/L & & 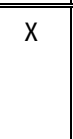 & & $\mathrm{x}$ & $x$ & & $\bar{x}$ & & 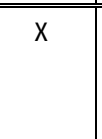 & $x$ & & & & & \\
\hline Luke Carpenter & Bainbridge Island Fire Dept. Chief & $\mathrm{L}$ & & $x$ & & $x$ & $x$ & $x$ & $x$ & & $x$ & $x$ & & & & & \\
\hline Russ Salter & $\begin{array}{l}\text { Battelle Crystal City Office of } \\
\text { Homeland Security }\end{array}$ & 0 & & & & & $x$ & & & $x$ & & & & & & & \\
\hline Dave Beyers & $\begin{array}{l}\text { Washington State DoE - Lead } \\
\text { WA State Emergency Response } \\
\text { Team }\end{array}$ & $\mathrm{S}$ & & $x$ & & & $x$ & $x$ & $x$ & $x$ & & $x$ & $x$ & & & & \\
\hline Beth Sheldrake & $\begin{array}{l}\text { USEPA Region } 10 \text { Emergency } \\
\text { Response - Spill Contingency } \\
\text { Planner }\end{array}$ & $\mathrm{F}$ & & $x$ & & & $x$ & & & & & $x$ & & & & & \\
\hline Tim Dunkle & $\begin{array}{l}\text { Pennsylvania Emergency } \\
\text { Management Agency/Penn. State } \\
\text { Fire Academy/ASTM EOP } \\
\text { Standard Guide }\end{array}$ & $\mathrm{S}$ & $x$ & $x$ & & $x$ & $x$ & $x$ & $x$ & $x$ & $x$ & $x$ & & & & $x$ & \\
\hline Dave Trebisacci & NFPA Standards & 0 & & $x$ & & $x$ & $x$ & & $x$ & & $x$ & $x$ & & & & & \\
\hline
\end{tabular}


Table A.1. (contd)

\begin{tabular}{|c|c|c|c|c|c|c|c|c|c|c|c|c|c|c|c|c|c|}
\hline \multirow[b]{2}{*}{ Participant } & \multirow[b]{2}{*}{ Organization } & \multirow[b]{2}{*}{$\begin{array}{l}\text { Fed / } \\
\text { State / } \\
\text { Local / } \\
\text { Other }\end{array}$} & \multicolumn{15}{|c|}{ ESF Disciplines } \\
\hline & & & 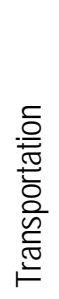 & 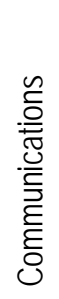 & 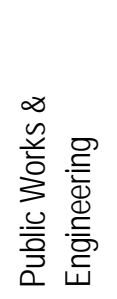 & 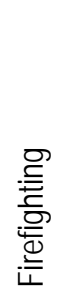 & 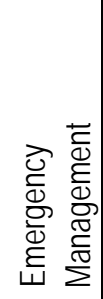 & 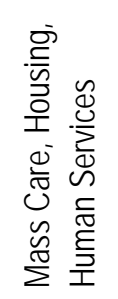 & 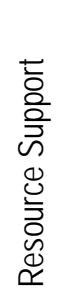 & 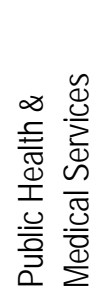 & 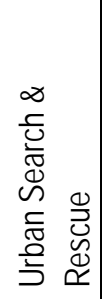 & 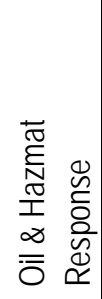 & 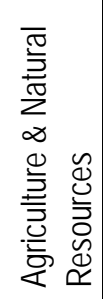 & 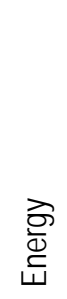 & 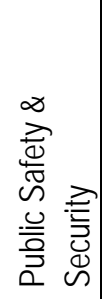 & 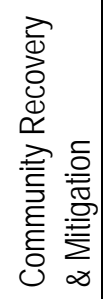 & 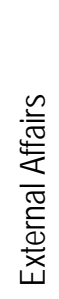 \\
\hline Amy Donahue & $\begin{array}{l}\text { UConn/Interagency Board \& } \\
\text { NIMS Development }\end{array}$ & 0 & & $\overline{\mathrm{x}}$ & & $\mathrm{x}$ & $\overline{\mathrm{x}}$ & & & $\bar{x}$ & & & & & $\bar{x}$ & & \\
\hline Ed Dadosky & $\begin{array}{l}\text { Cincinnati District Fire } \\
\text { Chief/EMA/EPA HSRC/Cincinnati } \\
\text { Police Academy }\end{array}$ & $\mathrm{L}$ & & $x$ & & $x$ & $x$ & $x$ & $x$ & & $x$ & $x$ & & & $x$ & $x$ & $\mathrm{x}$ \\
\hline Bob Gear & $\begin{array}{l}\text { Benton County Fire } \\
\text { Chief/National FEMA Overhead } \\
\text { Team Operations Chief }\end{array}$ & L & & $x$ & & $x$ & $x$ & $x$ & $x$ & & $x$ & $x$ & & & & & \\
\hline $\begin{array}{l}\text { James (Smokey) } \\
\text { Stanton }\end{array}$ & Homeland Security Institute & $\mathrm{F}$ & & $x$ & & $x$ & $x$ & $x$ & $x$ & & $x$ & $x$ & & & & $x$ & $\mathrm{x}$ \\
\hline Wayne Yoder & DHS - US Fire Administration & $\mathrm{F}$ & & $\mathrm{x}$ & & $x$ & $x$ & $x$ & $x$ & & $\mathrm{x}$ & $x$ & & & & & \\
\hline Charlie Brannon & NIST/DOE RAP Team & $\mathrm{F}$ & & $\mathrm{x}$ & $x$ & & $x$ & & $x$ & & & $x$ & & $x$ & & & \\
\hline Steve Stein & $\begin{array}{l}\text { PNNL/Regional Technology } \\
\text { Integration Initiative, Seattle Lead }\end{array}$ & 0 & $x$ & $x$ & $x$ & & $x$ & & $x$ & $x$ & & & $x$ & $x$ & & $x$ & \\
\hline Don Creighton & $\begin{array}{l}\text { PNNL/ Regional Technology } \\
\text { Integration Initiative, Cincinnati } \\
\text { Lead }\end{array}$ & 0 & $x$ & $x$ & $x$ & & $x$ & & $x$ & $x$ & & & $x$ & $x$ & & $x$ & \\
\hline Peter Shebell & DHS/NIC & $\mathrm{F}$ & & & & & & & & & & & & & & & \\
\hline Bill Rhodes & DHS/NIC & $\mathrm{F}$ & & & & & & & & & & & & & & & \\
\hline Bob Stenner & $\begin{array}{l}\text { PNNL/PI, ASTM E54 Standards, } \\
\text { NFPA Standards }\end{array}$ & 0 & & & $x$ & & $x$ & $x$ & & $x$ & & $x$ & $x$ & $x$ & & $x$ & \\
\hline
\end{tabular}




\section{Appendix B}

NIMS Standards Review Panel - Contact Information and PNNL Team List 
Table B.1. NIMS Standards Review Panel - Contact Information

\begin{tabular}{|c|c|}
\hline Name & Organization \\
\hline Don Olsen & Fire/IC Consultant for Regional Technology Integration Initiative \\
\hline Luke Carpenter* & Bainbridge Island Fire Chief \\
\hline Russ Salter & Battelle, Office of Homeland Security \\
\hline Dave Byers* & $\begin{array}{l}\text { Washington State Department of Ecology - Lead WA State Emergency } \\
\text { Response Team }\end{array}$ \\
\hline Beth Sheldrake & USEPA Region 10 Emergency Response - Spill Contingency Planner \\
\hline Tim Dunkle* & PEMA/Pennsylvania Fire Academy/ ASTM EOP standard \\
\hline Dave Trebisacci* & NFPA standards \\
\hline Amy Donahue & University of Connecticut / IAB \& NIMS Development \\
\hline Ed Dadosky & $\begin{array}{l}\text { Cincinnati District Fire Chief / OKI EMA / EPA HSRC / Cincinnati Police } \\
\text { Academy }\end{array}$ \\
\hline Bob Gear & $\begin{array}{l}\text { Benton County Fire Chief / National FEMA Overhead Team Operations } \\
\text { Section Chief }\end{array}$ \\
\hline Jim (Smokey) Stanton & Homeland Security Institute \\
\hline Wayne Yoder & DHS - US Fire Administration \\
\hline Charlie Brannon* & NIST \\
\hline Steve Stein & $\begin{array}{l}\text { Pacific Northwest National Laboratory } \\
\text { (PNNL) - Regional Technology Integration Initiative, Seattle Lead }\end{array}$ \\
\hline Don Creighton & PNNL - Regional Technology Integration Initiative, Cincinnati Lead \\
\hline Ryan Baggett & Eastern Kentucky University \\
\hline Pam Collins & Eastern Kentucky University \\
\hline Gary Suslavich & SAIC \\
\hline Peter Shebell & DHS NIC \\
\hline Bill Rhodes & DHS NIC \\
\hline Bob Stenner & PNNL - PI, ASTM E54 Standards, NFPA Standards \\
\hline
\end{tabular}

\begin{tabular}{|l|l||}
\hline \multicolumn{1}{|c|}{ E-Mail } & \multicolumn{1}{c|}{ Phone } \\
\hline workingolsen@aol.com & $509-586-3280$ \\
\hline Icarpenter@bifd.org & $206-842-7686$ \\
\hline SalterR@Battelle.org & $703-416-8186$ \\
\hline dbye461@ecy.wa.gov & $360-407-6974$ \\
\hline Sheldrake.Beth@epamail.epa.gov & $206-553-0220$ \\
\hline tdunkle@state.pa.us & $\begin{array}{l}717-248-1115 \\
\text { ext.107 }\end{array}$ \\
\hline dtrebisacci@nfpa.org & $617-984-7420$ \\
\hline amy.donahue@uconn.edu & $860-570-9343$ \\
\hline Edward.dadosky@cincinnati-oh.gov & $513-357-7521$ \\
\hline staff@bentonone.org & $509-734-9100$ \\
\hline James.stanton@hsi.dhs.gov & $703-416-3590$ \\
\hline wayne.yoder@dhs.gov & $301-447-1090$ \\
\hline cbrannon@nist.gov & $301-975-3855$ \\
\hline Stein@battelle.org & $206-528-3340$ \\
\hline don.creighton@pnl.gov & $509-375-2333$ \\
\hline ryan.baggett@eku.edu & Cell: 859-661-5416 \\
\hline pamcollins57@aol.com & Cell: 859-661-5116 \\
\hline gary.suslavich@saic.com & $606-274-2026$ \\
\hline peter.shebell@associates.dhs.gov & $202-646-2812$ \\
\hline william.rhodes@dhs.gov & $202-646-8246$ \\
\hline robert.stenner@pnl.gov & $509-375-2916$ \\
\hline & \\
\hline
\end{tabular}

* Could not attend workshop, but provided input in advance. 
Table B.2. PNNL Team Members

\begin{tabular}{|l|l|}
\hline \multicolumn{1}{|c|}{ Name } & \\
\hline \hline Robert Stenner & Project manager and standards review lead \\
\hline Kathleen Judd & Workshop Facilitator and pre-workshop coordination \\
\hline Gariann Gelston & Database development and information management \\
\hline Debbie Schwartz & Data management and pre-workshop support \\
\hline Jennifer Kirk & Workshop preparations support \\
\hline
\end{tabular}




\section{Appendix C}

\section{Template Responses with Category Rationale}


Appendix C. Template Responses with Category Rationale

\begin{tabular}{|c|c|c|c|c|c|c|c|c|c|}
\hline \multirow{2}{*}{$\begin{array}{c}\text { NIMS } \\
\text { Component }\end{array}$} & \multirow{2}{*}{$\begin{array}{l}\text { Standard } \\
\text { Number }\end{array}$} & \multirow[b]{2}{*}{ Standard Title } & \multirow[b]{2}{*}{ Standard Synopsis } & \multicolumn{4}{|c|}{$\begin{array}{c}\text { Category } \\
\text { Assignment Totals }\end{array}$} & \multirow[b]{2}{*}{ Category Rationale } & \multirow{2}{*}{$\begin{array}{c}\text { Related } \\
\text { Component }\end{array}$} \\
\hline & & & & $\mathrm{A}$ & $\mathrm{B}$ & $\mathrm{C}$ & $\mathrm{D}$ & & \\
\hline \multicolumn{10}{|c|}{ A. Command and Management } \\
\hline \multicolumn{10}{|c|}{ 1. Incident Command Structure } \\
\hline & NFPA 1561 & \begin{tabular}{|l} 
Standard on \\
Emergency Services \\
Incident \\
Management \\
Systems
\end{tabular} & $\begin{array}{l}\text { Outlines a management system, and } \\
\text { provides modular expansion } \\
\text { capabilities to manage resources at } \\
\text { an incident scene. It also provides } \\
\text { for a unified command approach to } \\
\text { incidents, which may be or become } \\
\text { mulit-jurisdictional or multi- } \\
\text { agency.(was Standard on Fire } \\
\text { Department Incident Management } \\
\text { Systems) }\end{array}$ & 9 & 2 & & & $\begin{array}{l}\text { A -- Bases for ICS as referenced in HSPD } 5 \\
\text { A -- In the main it addresses on scene incident management as it pertains to } \\
\text { multi-jurisdictional events. } \\
\text { It sets a foundation that should be incorporated in NIMS training. } \\
\text { A -- Category A because NIMS management system originated out of fire scope. } \\
\text { A lot within } 1561 \text { that should be included in NIMS. } \\
\text { A -- Addresses an important area in incident response - increasing resources at } \\
\text { the scene of the event. Also addresses unified command structure - important to } \\
\text { NIMS. } \\
\text { A -- Standard contains the minimum requirements for ICS and it states that ICS } \\
\text { is to be used by Emergency Services. } \\
\text { A -- Applies to multiple NIMS components; can be implemented in a practical } \\
\text { manner. } \\
\text { A -- Very important. } \\
\text { A -- One of two NFPA standards that are critical for Command and Control with } \\
\text { the other being } 1600 . \\
\text { B -- Directly applicable to incident command, but not sure how broadly used } \\
\text { and if up-to-date with NIMS. } \\
\text { B -- While this standard is widely recognized, it is not widely implemented on } \\
\text { the west coast. National Wildfire Coordinating Group( NWCG), National } \\
\text { Interagency Incident Management System (NIIMS) is more widely used on the } \\
\text { west coast. } \\
\text { INT: There is a need to come to consensus between what NFPA is publishing } \\
\text { and NIMS. }\end{array}$ & $\begin{array}{l}\text { A2, B1, B2, } \\
\text { B3, B4, B5, } \\
\text { B6, B7, C1 }\end{array}$ \\
\hline
\end{tabular}


Table C. (contd)

\begin{tabular}{|c|c|c|c|c|c|c|c|c|c|}
\hline \multirow{2}{*}{$\begin{array}{c}\text { NIMS } \\
\text { Component }\end{array}$} & \multirow{2}{*}{$\begin{array}{l}\text { Standard } \\
\text { Number }\end{array}$} & \multirow[b]{2}{*}{ Standard Title } & \multirow[b]{2}{*}{ Standard Synopsis } & \multicolumn{4}{|c|}{$\begin{array}{c}\text { Category } \\
\text { Assignment Totals }\end{array}$} & \multirow[b]{2}{*}{ Category Rationale } & \multirow{2}{*}{$\begin{array}{c}\text { Related } \\
\text { Components }\end{array}$} \\
\hline & & & & $\mathrm{A}$ & $\mathrm{B}$ & $\mathrm{C}$ & $\mathrm{D}$ & & \\
\hline \multicolumn{10}{|c|}{ A. Command and Management } \\
\hline & NENA-01-002 & $\begin{array}{l}\text { NENA (National } \\
\text { Emergency Number } \\
\text { Assoc.) Master } \\
\text { Glossary of 9-1-1 } \\
\text { Terminology }\end{array}$ & $\begin{array}{l}\text { Defines terms, acronyms, and } \\
\text { definitions regarding the 9-1-1 }\end{array}$ & 8 & & 1 & 1 & $\begin{array}{l}\text { A -- Applies standardized terminology. Needed for consistency. } \\
\text { A -- Common lexicon is essential. } \\
\text { Effectiveness and efficiency depend on communications and a common } \\
\text { language is a requirement. } \\
\text { A -- Commonly accepted terminology. } \\
\text { A -- Interoperability, common terminology } \\
\text { A -- Needed for definition of terms and should be the master for all terms to be } \\
\text { associated with NIMS. } \\
\text { A -- There needs to be a commonality between terminology, acronyms, and } \\
\text { definitions. Across the country we don't have a universal system. } 911 \text { is the } \\
\text { easiest } \\
\text { A -- This standard is very widely used by most Public Safety Answering Points } \\
\text { (PSAPs). Common terminology and communications among communications } \\
\text { centers is essential in resource management. } \\
\text { INT: It is critical that communication center standardization happens first. } \\
\text { C -- Don't have knowledge of this standard to make a fair evaluation. }\end{array}$ & $\mathrm{B} 4, \mathrm{D} 1$ \\
\hline & NFPA 1600 & $\begin{array}{l}\text { Standard on } \\
\text { Disaster/Emergency } \\
\text { Management and } \\
\text { Business Continuity } \\
\text { Programs }\end{array}$ & $\begin{array}{l}\text { Minimum criteria for disaster } \\
\text { management and provides guidance } \\
\text { to the private and public sectors in } \\
\text { the development of a program for } \\
\text { effective disaster preparedness } \\
\text { response and recovery. }\end{array}$ & 10 & 1 & & & $\begin{array}{l}\text { A -- Accepted preparedness standard and is basis for the standard used by } \\
\text { emergency management accreditation program. } \\
\text { A -- Widely used and very familiar to first responders. Must incorporate in } \\
\text { NIMS. } \\
\text { A -- Applies to multiple NIMS components; can be implemented in a practical } \\
\text { manner. } \\
\text { A -- Establishes a common set of criteria for disaster management, emergency } \\
\text { management and business continuity programs. } \\
\text { A -- Provides a common set of criteria for emergency management.Supports } \\
\text { numerous elements. } \\
\text { A -- Provides common approach for multi-agency coordination } \\
\text { A -- The second most important NFPA standard that defines the command and } \\
\text { control functions of NIMS. } \\
\text { A -- There is a great benefit in having both public and private sectors on same } \\
\text { page for business continuity } \\
\text { A -- This standard focuses on actions/activities related to business/buildings. It } \\
\text { speaks to the building managers responsibilities in working with emergency } \\
\text { responders incident commander. INT: Building mgrs and firefighters must speak } \\
\text { the same language. Large buildings must be managed like a community in itself. }\end{array}$ & $\begin{array}{l}\text { A2, B1, B2, } \\
\text { B3, B4, B5, } \\
\text { B6, B7, C1, } \\
\text { D2 }\end{array}$ \\
\hline
\end{tabular}


Table C. (contd)

\begin{tabular}{|c|c|c|c|c|c|c|c|c|c|}
\hline \multirow{2}{*}{$\begin{array}{c}\text { NIMS } \\
\text { Component }\end{array}$} & \multirow{2}{*}{$\begin{array}{l}\text { Standard } \\
\text { Number }\end{array}$} & \multirow[b]{2}{*}{ Standard Title } & \multirow[b]{2}{*}{ Standard Synopsis } & \multicolumn{4}{|c|}{$\begin{array}{c}\text { Category } \\
\text { Assignment Totals }\end{array}$} & \multirow[b]{2}{*}{ Category Rationale } & \multirow{2}{*}{$\begin{array}{c}\text { Related } \\
\text { Components }\end{array}$} \\
\hline & & & & $\mathrm{A}$ & $\mathrm{B}$ & $\mathrm{C}$ & $\mathrm{D}$ & & \\
\hline \multicolumn{10}{|c|}{ A. Command and Management } \\
\hline & & $\begin{array}{l}\text { ASTM 2413- } \\
\text { 04/HEICS III } \\
\text { Hospital Emergency } \\
\text { Incident Command } \\
\text { System (1992) }\end{array}$ & $\begin{array}{l}\text { Describes Incident Command } \\
\text { System for Hospitals }\end{array}$ & 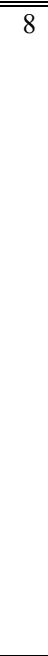 & 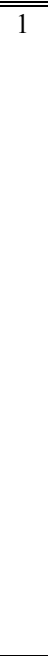 & 1 & & $\begin{array}{l}\text { A - Developed based on ICS before NIMS. Being used. Important to include in } \\
\text { NIMS. } \\
\text { A -- Directly applies. } \\
\text { A -- Important from hospital and public health perspectives. } \\
\text { A -- In addition to this standard would also suggest looking at new ASTM E54 } \\
\text { Standard - but this standard clearly defines the C \& C for Hospitals. } \\
\text { A -- JCA requires health care facilities to use Incident Command structure where } \\
\text { they are located. } \\
\text { A -- This standard is essential for all hospitals to implement as part of their } \\
\text { accreditation. } \\
\text { INT: the hospital picture has largely been missing. Most training is based on the } \\
\text { MAC curriculum. } \\
\text { A -- While not an adopted standard by a SDO, the program has been widely } \\
\text { accepted } \\
\text { B -- Applies to hospital accreditation; maybe needs more formal adoption or } \\
\text { possibly linkage to the NFPA } 473 \text { updating and ASTM E2413-04 as they are } \\
\text { being linked. } \\
\text { C -- Not familiar with this standard; cannot make a fair evaluation. }\end{array}$ & $\begin{array}{l}\mathrm{A} 2, \mathrm{~B} 1, \mathrm{~B} 2 \\
\mathrm{~B} 3, \mathrm{~B} 4, \mathrm{~B} 5 \\
\mathrm{~B} 6, \mathrm{~B} 7, \mathrm{C} 1 \\
\text { D1 }\end{array}$ \\
\hline & & $\begin{array}{l}\text { Emergency } \\
\text { Management } \\
\text { Accreditation } \\
\text { Program (EMAP) }\end{array}$ & $\begin{array}{l}\text { Voluntary assessment and } \\
\text { accreditation process based on } \\
\text { NFPA } 1600 \text {. Criteria to assess } \\
\text { current programs or to develop, } \\
\text { implement, and maintain a program } \\
\text { to mitigate, prepare for, respond to, } \\
\text { and recover from disasters and } \\
\text { emergencies. }\end{array}$ & 3 & 3 & 1 & 3 & $\begin{array}{l}\text { A -- Much needed review format for ensuring NFPA } 1600 \text { is applicable to and } \\
\text { serves the needs of the states and locals. } \\
\text { B -- EMAP is a pre-event "standard" providing criteria for comprehensive } \\
\text { preparedness. } \\
\text { B -- Not sure how up-to-date and compatible with NIMS. } \\
\text { C -- Not familiar with this standard; cannot make a fair evaluation. } \\
\text { D -- Covered in NFPA 1600--this is the plan for how to prove compliance-- } \\
\text { NFPA } 1600 \text { is the standard. } \\
\text { D -- I don't believe that most of the current Emergency Management curriculum } \\
\text { is compatible with NIMS } \\
\text { D -- This program should exist in preparedness }\end{array}$ & $\begin{array}{l}\mathrm{B} 1, \mathrm{~B} 2, \mathrm{~B} 3 \\
\mathrm{~B} 4, \mathrm{~B} 5, \mathrm{~B} 6 \\
\mathrm{~B} 7, \mathrm{C} 1\end{array}$ \\
\hline & $\begin{array}{l}\text { (Other) PMS } \\
310-1\end{array}$ & $\begin{array}{l}\text { National Wildfire } \\
\text { Coordinating Group, } \\
\text { (NWCG) } \\
\text { Publications } \\
\text { Management } \\
\text { Systems (PMS) } \\
\text { document 310-1 }\end{array}$ & $\begin{array}{l}\text { The } 310-1 \text { standards are the most } \\
\text { widely used on the west coast. } \\
\text { These standards describe the } \\
\text { training and experience } \\
\text { requirements for all ICS positions. }\end{array}$ & 1 & & & & $\begin{array}{l}\text { A -- This standard has been adopted and used by all Federal and State Wildfire } \\
\text { agencies on the West Coast. It is also the basis for training done by the U.S. } \\
\text { Coast Guard for oil spill response. Many local government agencies have also } \\
\text { adopted this standard. }\end{array}$ & $\mathrm{A} 2, \mathrm{~B} 2, \mathrm{~B} 4$ \\
\hline
\end{tabular}


Table C. (contd)

\begin{tabular}{|c|c|c|c|c|c|c|c|c|c|}
\hline \multirow{2}{*}{$\begin{array}{l}\text { NIMS } \\
\text { Component }\end{array}$} & \multirow{2}{*}{$\begin{array}{l}\text { Standard } \\
\text { Number }\end{array}$} & \multirow[b]{2}{*}{ Standard Title } & \multirow[b]{2}{*}{ Standard Synopsis } & \multicolumn{4}{|c|}{$\begin{array}{c}\text { Category } \\
\text { Assignment Totals } \\
\end{array}$} & \multirow[b]{2}{*}{ Category Rationale } & \multirow{2}{*}{$\begin{array}{c}\text { Related } \\
\text { Components }\end{array}$} \\
\hline & & & & A & $\mathrm{B}$ & $\mathrm{C}$ & $\mathrm{D}$ & & \\
\hline \multicolumn{10}{|c|}{ A. Command and Management } \\
\hline & (Other) & $\begin{array}{l}\text { National } \\
\text { Contingency Plan } \\
(40 \text { CFR 300) } \\
\end{array}$ & $\begin{array}{l}\text { Requires use of an incident } \\
\text { management system for oil and } \\
\text { hazardous substance response }\end{array}$ & & 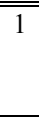 & & & $\begin{array}{l}\text { B -- INT: NCP addresses incident mgt for Superfund and spills and says EPA is } \\
\text { required to use this system. Is generally consistent with NIMS. }\end{array}$ & \\
\hline & (Other) & & EMAC Legislation & 1 & & & & $\begin{array}{l}\text { A -- Other EMAC Legislation enables the legislation between the states. } 48 \\
\text { states have done this. }\end{array}$ & \\
\hline & $\begin{array}{l}\text { (Other) NFPA } \\
1021\end{array}$ & $\begin{array}{l}\text { Standard for Fire } \\
\text { Officer Professional } \\
\text { Qualifications } \\
(2003) \\
\end{array}$ & $\begin{array}{l}\text { Competencies for Fire Officer } \\
\text { Professionals }\end{array}$ & 1 & & & & A -- Applies to ICS of NIMS and is easily implemented. & \\
\hline & $\begin{array}{l}\text { (Other) ASTM } \\
\text { Hospital } \\
\text { Standard }\end{array}$ & & & & & & & & \\
\hline \multicolumn{10}{|c|}{ 2. Multiagency Coordination Systems } \\
\hline & & \begin{tabular}{|l} 
Emergency \\
Management \\
Standards for Health \\
Care Organizations \\
and Their \\
Communities
\end{tabular} & $\begin{array}{l}\text { Common set of criteria for disasters } \\
\text { and emergency management } \\
\text { programs in both the public and } \\
\text { private sectors. }\end{array}$ & 2 & 3 & 4 & & $\begin{array}{l}\text { A -- Health/hospital overlap. } \\
\text { B -- Only portions of this document are applicable to Multi-agency coordination } \\
\text { B -- Probably needed but not sure this is critical to NIMS. } \\
\text { C -- May apply but need more information. } \\
\text { C -- Needs to be explored; standards for health organizations and communities is } \\
\text { needed; just not sure how much and how up-to-date with NIMS } \\
\text { C -- Not familiar with this standard; cannot make a fair evaluation. }\end{array}$ & $\begin{array}{l}\text { B1, B2, B3, } \\
\text { B4, B5, B6, } \\
\text { B7 }\end{array}$ \\
\hline & EC.1.4 & $\begin{array}{l}\text { Environment of Care } \\
\text { 1.4, Emergency } \\
\text { Management } \\
\text { Standard }\end{array}$ & $\begin{array}{l}\text { Describes how the organization will } \\
\text { establish and maintain a program to } \\
\text { ensure effective response to } \\
\text { disasters or emergencies affecting } \\
\text { the environment of care. The plan } \\
\text { should address four phases of } \\
\text { emergency management activities: } \\
\text { mitigation, preparedness, response, } \\
\text { and recovery. }\end{array}$ & 3 & 3 & 4 & & $\begin{array}{l}\text { A -- Probably one of the few standards that looks at all phases and should be } \\
\text { incorporated for the NIMS process. } \\
\text { B -- Elements address NIMS but much is relevant only to environmental } \\
\text { protection. } \\
\text { B -- Provides pre-event planning standards and criteria. Mandated for } \\
\text { hospitals. } \\
\text { C -- More information needed } \\
\text { C -- Not familiar with this standard; cannot make a fair evaluation. }\end{array}$ & $\begin{array}{l}\text { B1, B2, B3, } \\
\text { B4, B5, B6, } \\
\text { B7, C1 }\end{array}$ \\
\hline
\end{tabular}


Table C. (contd)

\begin{tabular}{|c|c|c|c|c|c|c|c|c|c|}
\hline \multirow{2}{*}{$\begin{array}{l}\text { NIMS } \\
\text { Component }\end{array}$} & \multirow{2}{*}{$\begin{array}{l}\text { Standard } \\
\text { Number }\end{array}$} & \multirow[b]{2}{*}{ Standard Title } & \multirow[b]{2}{*}{ Standard Synopsis } & \multicolumn{4}{|c|}{$\begin{array}{c}\text { Category } \\
\text { Assignment Totals }\end{array}$} & \multirow[b]{2}{*}{ Category Rationale } & \multirow{2}{*}{$\begin{array}{c}\text { Related } \\
\text { Components }\end{array}$} \\
\hline & & & & $\mathrm{A}$ & $\mathrm{B}$ & $\mathrm{C}$ & $\mathrm{D}$ & & \\
\hline \multicolumn{10}{|c|}{ A. Command and Management } \\
\hline & & $\begin{array}{l}\text { Comprehensive } \\
\text { Accreditation } \\
\text { Manual for Hospitals } \\
\text { (CAMH) } \\
\text { (was Comprehensive } \\
\text { Hospital } \\
\text { Accreditation) }\end{array}$ & $\begin{array}{l}\text { Accreditation of hospitals, requiring } \\
\text { emergency management plans, } \\
\text { specifically incorporating disaster } \\
\text { management elements mitigation, } \\
\text { preparedness, response and } \\
\text { recovery. Also requirements for } \\
\text { regular training and exercises in } \\
\text { emergency management. }\end{array}$ & 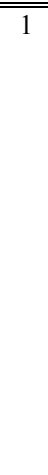 & 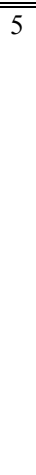 & 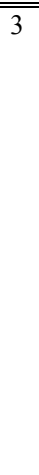 & 1 & $\begin{array}{l}\text { B -- Although very important to hospitals unless the plans incorporate the whole } \\
\text { communities hospitals and not just a single hospital then this would not be the } \\
\text { best standard. } \\
\text { B -- Another pre-event planning standard. Disaster response element is } \\
\text { pertinent. } \\
\text { B -- Joint Commission on the Accreditation of Health Care Organizations } \\
\text { (JCAHO) - CAMH is cited in the ASTM E2413-04 Hospital Preparedness } \\
\text { Standard; maybe this citing in E2413-04 is all that is needed to link this one and } \\
\text { it is applied by JCAHO. } \\
\text { B -- Need to know more. Clearly related but generally insular. } \\
\text { C -- Not familiar with this standard; cannot make a fair evaluation. } \\
\text { D -- Accreditation is a preparedness, and resource management. Concern. Do we } \\
\text { want to base a standard on a manual? }\end{array}$ & \\
\hline & & $\begin{array}{l}\text { Superfund } \\
\text { Emergency } \\
\text { Response Program } \\
\text { (PSTAA) }\end{array}$ & $\begin{array}{l}\text { Program provides quick response to } \\
\text { the release, or threatened release, of } \\
\text { hazardous substances. The program } \\
\text { utilizes federal, state and local } \\
\text { cooperation, and the National } \\
\text { Response system to effectively } \\
\text { protect the public and the } \\
\text { environment from immediate threats } \\
\text { posed by hazardous substances. }\end{array}$ & 3 & 3 & 3 & 2 & $\begin{array}{l}\text { A -- Know a little about this standard but probably can be better addressed by } \\
\text { others in the group. } \\
\text { A -- National Response System guidance and standards must be incorporated in } \\
\text { national incident command. Federal agencies in the NRS perform a significant } \\
\text { function in response to hazardous substances. } \\
\text { B -- INT: Provides lots of standards and requirements that EPA must follow } \\
\text { with respect to "how clean is clean", cost issues, how to involve communities, } \\
\text { etc. While not "essential" for NIMS compliance, NIC should be aware that this } \\
\text { exists. } \\
\text { B -- Parts are applicable to multi-agency coordination } \\
\text { C -- Needs updating in ICS } \\
\text { C -- Not familiar with this standard; cannot make a fair evaluation. } \\
\text { D -- Superfund targets restoration, only a small element relates to emergency } \\
\text { response. RCRA is more appropriate. }\end{array}$ & \\
\hline & & $\begin{array}{l}\text { APWA } \\
\text { Accreditation And } \\
\text { Self-Assessment }\end{array}$ & $\begin{array}{l}\text { The purpose of the accreditation } \\
\text { program is to provide a means of } \\
\text { formally verifying and recognizing } \\
\text { public works agencies for } \\
\text { compliance with the recommended } \\
\text { practices set forth in the Public } \\
\text { Works Management Practices } \\
\text { Manual }\end{array}$ & 1 & 1 & 7 & & $\begin{array}{l}\text { C -- More information is needed to assess } \\
\text { C -- Not familiar with this standard; cannot make a fair evaluation. }\end{array}$ & \\
\hline
\end{tabular}


Table C. (contd)

\begin{tabular}{|c|c|c|c|c|c|c|c|c|c|}
\hline \multirow{2}{*}{$\begin{array}{c}\text { NIMS } \\
\text { Component }\end{array}$} & \multirow{2}{*}{$\begin{array}{l}\text { Standard } \\
\text { Number }\end{array}$} & \multirow[b]{2}{*}{ Standard Title } & \multirow[b]{2}{*}{ Standard Synopsis } & \multicolumn{4}{|c|}{$\begin{array}{c}\text { Category } \\
\text { Assignment Totals } \\
\end{array}$} & \multirow[b]{2}{*}{ Category Rationale } & \multirow{2}{*}{$\begin{array}{c}\text { Related } \\
\text { Components }\end{array}$} \\
\hline & & & & $\mathrm{A}$ & $\mathrm{B}$ & $\mathrm{C}$ & $\mathrm{D}$ & & \\
\hline \multicolumn{10}{|c|}{ A. Command and Management } \\
\hline & \begin{tabular}{|l} 
(Other) \\
NWCG I-401
\end{tabular} & $\begin{array}{l}\text { Multi Agency } \\
\text { Coordination Group }\end{array}$ & $\begin{array}{l}\text { Provides basic training and } \\
\text { introduction to Multi-Agency } \\
\text { Coordinating Group roles and } \\
\text { responsibilities. } \\
\end{array}$ & 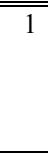 & & & & $\begin{array}{l}\text { A -- Currently most commonly used curriculum to introduce a community to the } \\
\text { MAC concept. }\end{array}$ & $\overline{\mathrm{A} 1, \mathrm{C} 1}$ \\
\hline & (Other) & $\begin{array}{l}\text { National } \\
\text { Contingency Plan } \\
\text { (40 CFR 300), } \\
\text { Comprehensive } \\
\text { Environmental } \\
\text { Response } \\
\text { Compensation and } \\
\text { Liability Act } \\
\text { (CERCLA) and } \\
\text { Clean Water Act as } \\
\text { amended by the Oil } \\
\text { Pollution Act (OPA) }\end{array}$ & $\begin{array}{l}\text { NCP, CERCLA, and the Clean } \\
\text { Water Act as amended by the Oil } \\
\text { Pollution Act of } 1990 \text { require } \\
\text { coordination among federal, state, } \\
\text { local, and tribal response } \\
\text { organizations. This is accomplished } \\
\text { through a National Response Team } \\
\text { with representatives from } 16 \text { federal } \\
\text { agencies, } 13 \text { Regional Response } \\
\text { Teams, and numerous Area } \\
\text { Committees throughout the country. } \\
\text { The NRT, RRTs, and Area } \\
\text { Committees are required to develop } \\
\text { spill contingency plans and conduct } \\
\text { exercises to be better prepared to } \\
\text { respond to oil and hazardous } \\
\text { substance releases. }\end{array}$ & & 1 & & & $\begin{array}{l}\text { B -- INT: Establishes legal requirements for national and regional response } \\
\text { teams. This must also be consistent with NIMS. Need this to continue to exist of } \\
\text { things that don't require NRP being activated. }\end{array}$ & \\
\hline & \begin{tabular}{|l|} 
(Other) RCRA \\
\end{tabular} & & $\begin{array}{l}\text { Hazardous Waste Management and } \\
\text { cleanup }\end{array}$ & & 1 & & & $\begin{array}{l}\text { B -- Address hazardous waste management operations and response including } \\
\text { authorities and responsibilities. }\end{array}$ & \\
\hline \multicolumn{10}{|c|}{ 3. Public Information System } \\
\hline & NFPA 1600 & \begin{tabular}{|l|} 
Standard on \\
Disaster/Emergency \\
Management and \\
Business Continuity \\
Programs
\end{tabular} & $\begin{array}{l}\text { Establishes a common set of criteria } \\
\text { for disaster management, emergency } \\
\text { management, and business } \\
\text { continuity programs }\end{array}$ & 7 & 4 & & & $\begin{array}{l}\text { A -- Already provide justification. } \\
\text { A -- Applies to multiple NIMS components; easily implemented. } \\
\text { A -- See above comments } \\
\text { A -- Synopsis states the reasoning,. } \\
\text { A -- There is a great benefit in having both public and private sectors on same } \\
\text { page for business continuity. } \\
\text { B -- IC and preparedness criteria for disaster emergency management. } \\
\text { B -- Paragraph 5.14 pertinent to public information. Requires system. } \\
\text { B -- Sets criteria for disaster/emergency management. }\end{array}$ & $\begin{array}{l}\text { B1, B2, B3, } \\
\text { B4, B5, B6, } \\
\text { B7 }\end{array}$ \\
\hline
\end{tabular}


Table C. (contd)

\begin{tabular}{|c|c|c|c|c|c|c|c|c|c|}
\hline \multirow{2}{*}{$\begin{array}{c}\text { NIMS } \\
\text { Component }\end{array}$} & \multirow{2}{*}{$\begin{array}{l}\text { Standard } \\
\text { Number }\end{array}$} & \multirow[b]{2}{*}{ Standard Title } & \multirow[b]{2}{*}{ Standard Synopsis } & \multicolumn{4}{|c|}{$\begin{array}{c}\text { Category } \\
\text { Assignment Totals }\end{array}$} & \multirow[b]{2}{*}{ Category Rationale } & \multirow{2}{*}{$\begin{array}{c}\text { Related } \\
\text { Components }\end{array}$} \\
\hline & & & & $\mathrm{A}$ & $\mathrm{B}$ & $\mathrm{C}$ & $\mathrm{D}$ & & \\
\hline \multicolumn{10}{|c|}{ A. Command and Management } \\
\hline & & $\begin{array}{l}\text { AMBER Alert } \\
\text { Message Schema } \\
\text { [Based on the } \\
\text { operational version } \\
\text { 3.0 of the Global } \\
\text { Justice XML Data } \\
\text { Model] }\end{array}$ & $\begin{array}{l}\text { Still in draft for, proposed as a } \\
\text { baseline standard to promote the } \\
\text { seamless sharing of AMBER Alert } \\
\text { Information and between } \\
\text { jurisdictions and the technologies } \\
\text { they employ. }\end{array}$ & 3 & 2 & 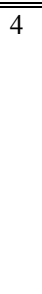 & & $\begin{array}{l}\text { A -- Alert must be standardized as part of NIMS. AMBER will be in place. } \\
\text { Should be emergency XML standard that is multi-jurisdictional. } \\
\text { A -- Could see this as being a very important communication element. } \\
\text { A -- Requires all the elements. } \\
\text { B -- Needed, but not sure how far along and how complete. Linking AMBER } \\
\text { alert systems with emergency response is a technology focus. } \\
\text { C -- Not familiar with this standard; cannot make a fair evaluation. } \\
\text { C -- Would AMBER system be available for use in national emergencies? }\end{array}$ & \\
\hline & $\begin{array}{l}\text { (Other) NFPA } \\
1035\end{array}$ & $\begin{array}{l}\text { NFPA } 1035 \\
\text { Standard for } \\
\text { Professional } \\
\text { Qualifications for } \\
\text { Public Fire and Life } \\
\text { Safety Educator } \\
\text { 2005 Edition }\end{array}$ & $\begin{array}{l}\text { Chapter 8, Public Information } \\
\text { Officer }\end{array}$ & & 1 & & & & $\mathrm{~B} 2$ \\
\hline & (Other) & $\begin{array}{l}\text { EMAC } \\
\text { DICTIONARY }\end{array}$ & & 1 & & & & $\begin{array}{l}\text { A -- EMAC Dictionary - EMAC has a certain set of definitions that are used to } \\
\text { facilitate interstate transfer of assets and territories. Some of those definitions } \\
\text { should be used to facilitate a NIMS sort of work. }\end{array}$ & \\
\hline
\end{tabular}




\section{Appendix D}

\section{Database Development}




\section{Appendix D \\ Database Development}

The following summarizes the database development activities of the project.

\section{D.1 Database Overview}

The National Incident Management System (NIMS) standards database was developed (using Microsoft Access) to serve as a decision making tool during the workshop and to assist the NIMS Integration Center (NIC) in the subsequent creation of an Essential Standards List for the NIMS. The database was designed to meet the following performance objectives. It would be:

- $\quad$ easy to read and navigate through the database when projected

- easy to add data in real-time

- accommodate multiple cross-references for data analysis

- generate a number of reports describing:

0 the standards most frequently designated as Category A and B

0 the rationale provided by panel members with respect to the category assignments

0 the Emergency Support Function (ESF) disciplines associated with each standard

o the pros, cons, and conditions for adoption discussed during the workshop.

As noted previously in this report, several panel members completed a template before the workshop in which they assigned each standard to a category and provided a rationale for their choice. All participant responses, including any new standards added, were entered into the database before the workshop convened. The workshop coordination team also entered into the database the information on ESF disciplines determined to be relevant to each Category A and B standard.

\section{D.2 Database Architecture}

The NIMS Database Main Menu (Figure D.1) contains the selections for the Input and Reporting screens.

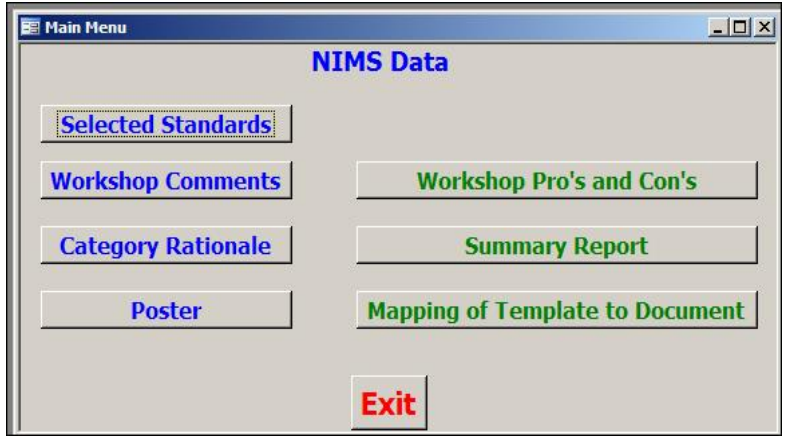

Figure D.1. The NIMS Database Main Menu 
It is used to guide the user to the specific working-level screens where data input and retrieval functions occur. The main menu screen appears when the user clicks twice on the database file.

The Selected Standards screen (Figure D.2) contains the 12 standards most frequently identified as Category A and B by the panel members. This is an input screen for the Pros, Cons, and Conditions data that was captured during the workshop.

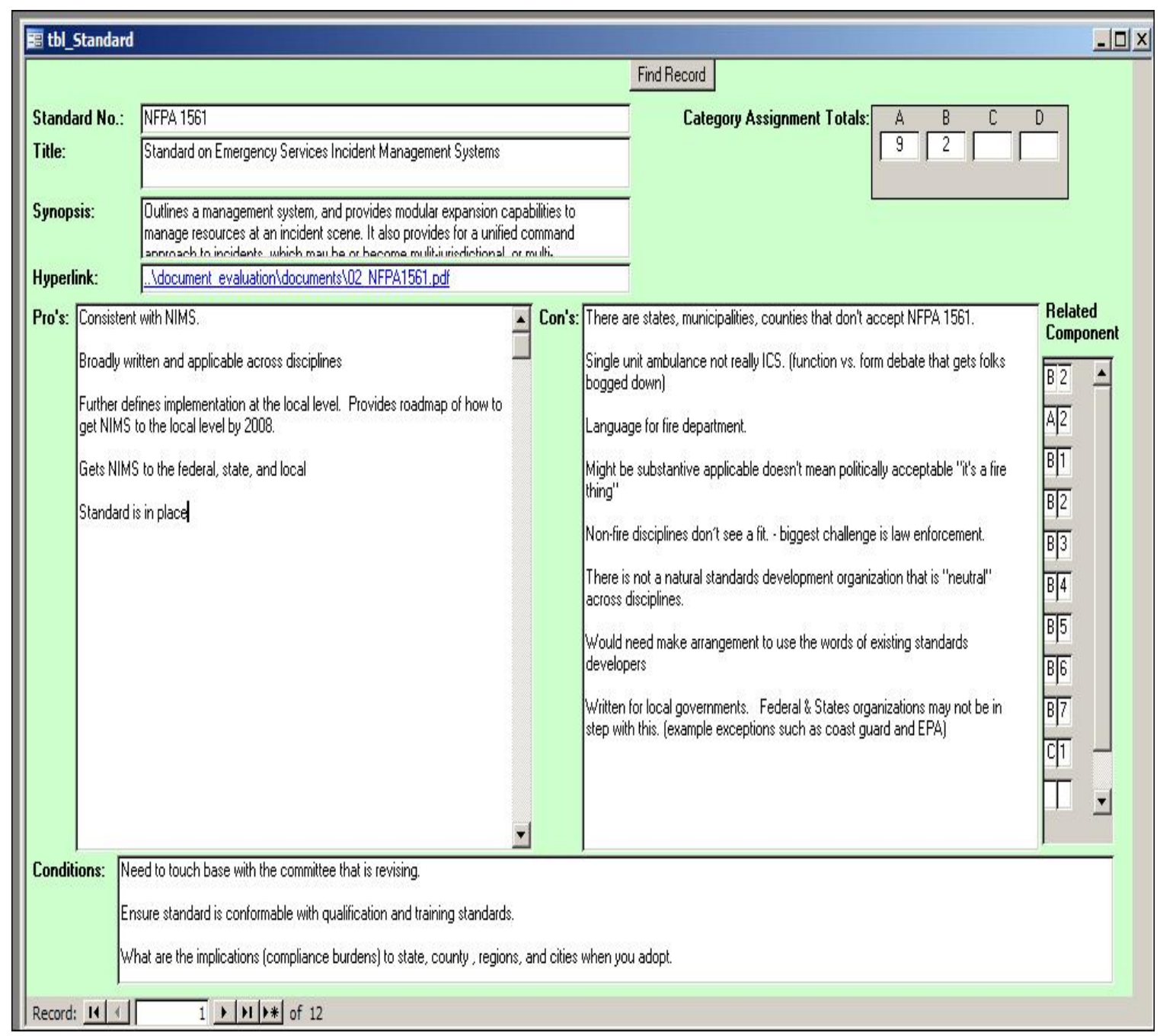

Figure D.2 The Selected Standards Screen

The Workshop Comments screen (Figure D.3) contains all of the standards from the initial standards inventory and any standards added by the participants. This is an input screen for capturing date on the Pros, Cons, and Conditions for adoption for standards other than the 12 selected standards above.

The Category Rationale report lists each standard by component and subcomponent. It includes the total count for each category selection (A, B, C, and D) and the rationale provided by panel members for the category selection. A copy of this report was provided in the workshop binder. 
The Poster report (Figure D.4) was designed to display the 12 standards most frequently cited as Category A and B standards, and their associated ESF disciplines, in a poster format to facilitate review during the workshop.

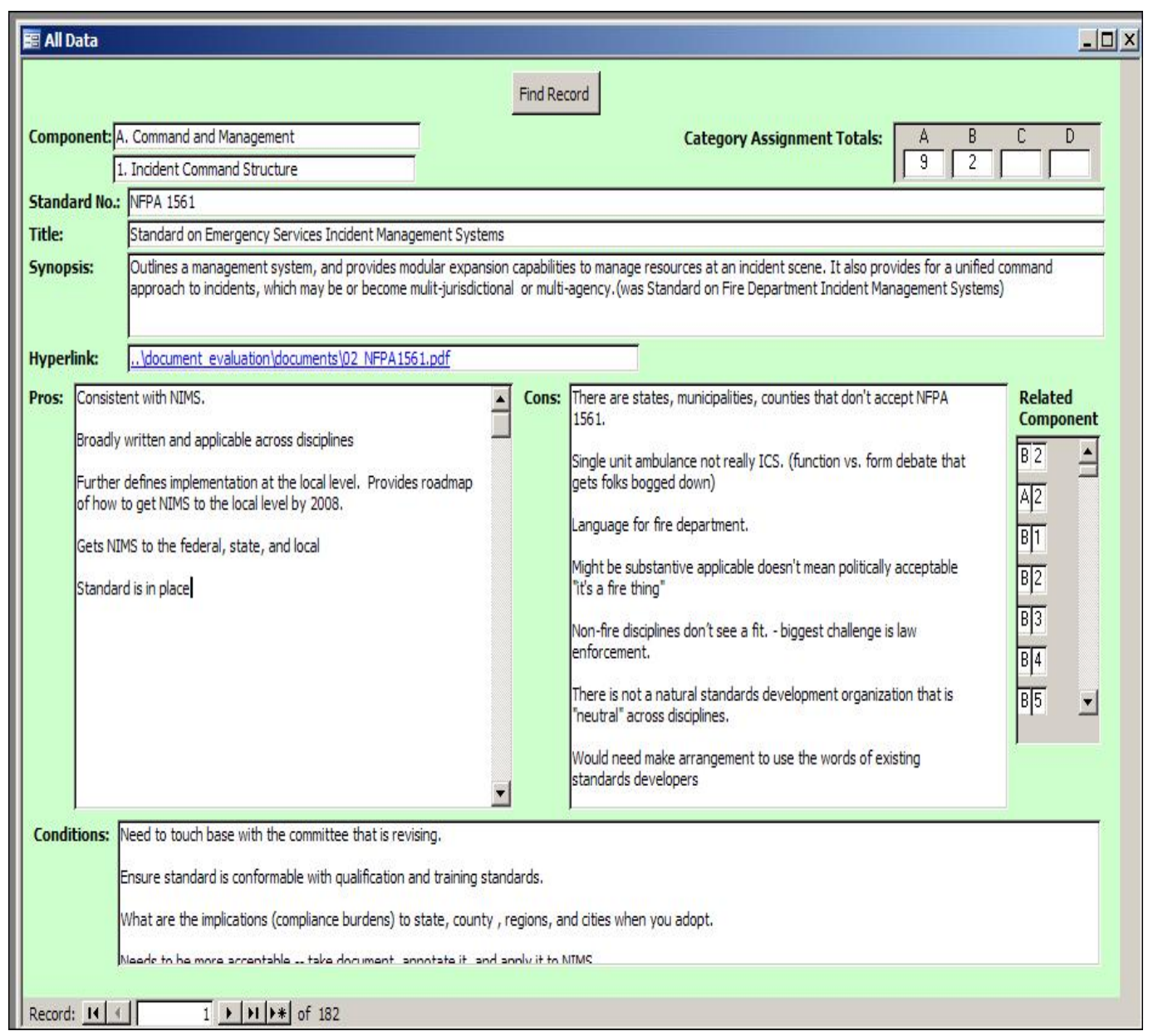

Figure D.3. The Workshop Comments screen 


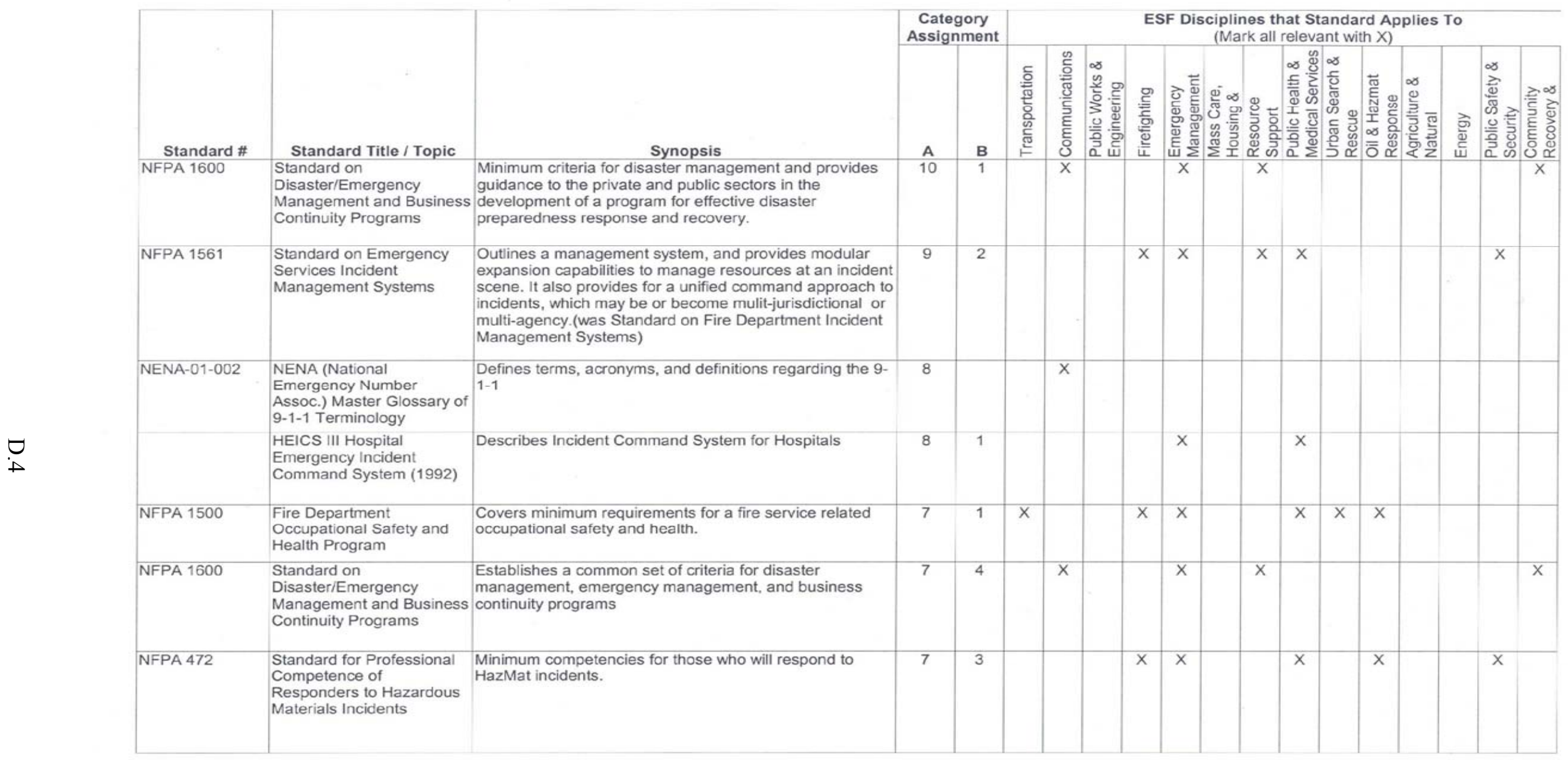

Figure D.4 The Poster Report 
The Workshop Pros and Cons report (Figure D.5) lists each standard by NIMS component and subcomponent and describes the Pros, Cons, and Conditions for Adoption captured during the workshop. A copy of the report was provided in the workshop binder.

The Summary Report (Figure D.6) lists each standard by NIMS component and subcomponent, other components that the standard supports, the total count for each of the category selections, and the applicable ESF disciplines for each standard. A copy of the report was provided in the workshop binder.

Finally, the database includes a panel member contact list (provided in Appendix B of this report). 
Workshop Pro's and Con's

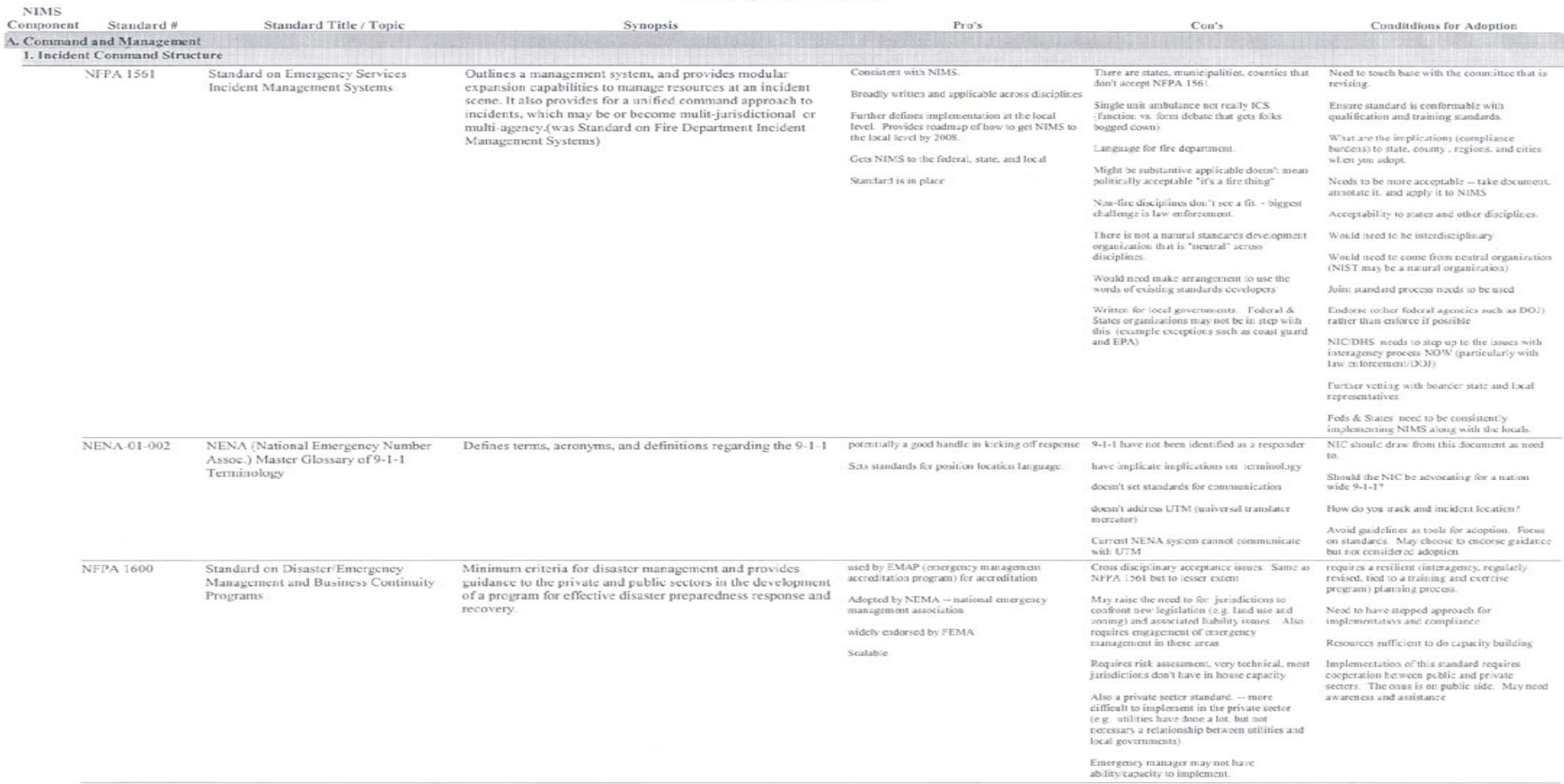

Figure D.5. The Workshop Pros and Cons Report 


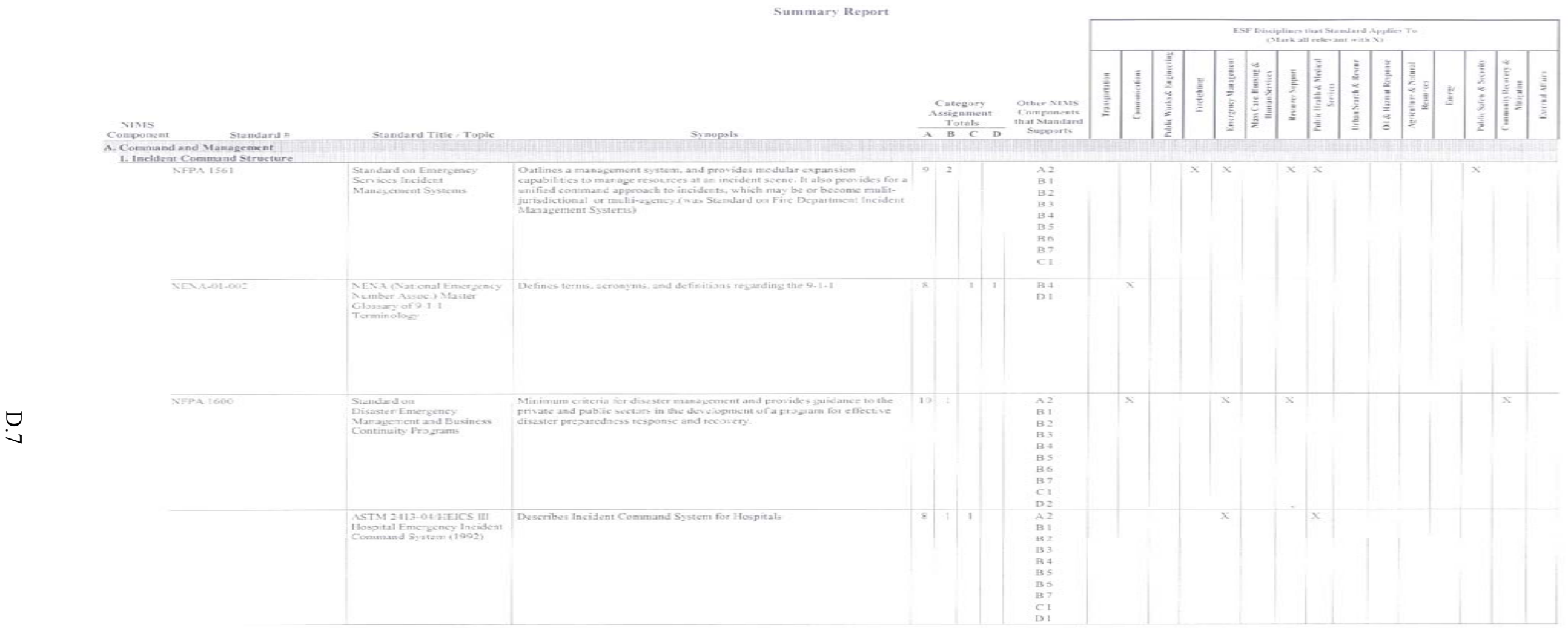

Figure D.6. The Summary Report 


\section{Appendix E}

Framework and Pros/Cons/Conditions Summary for Each Standard 


\section{Appendix E}

\section{Framework and Pros/Cons/Conditions Summary for Each Standard}

The framework and pros/cons/conditions are summarized below for each selected standard.

\section{E.1 NFPA 1561: Standard on Emergency Services Incident Management Systems}

Panel Assessment:

- NIMS Component/Subcomponent Supported:

- Command and Management

- Preparedness

- Resource Management

- Communications and Information Management

- Ongoing Management and Maintenance

- Relevant Disciplines: Applies to all

- Level of government: Federal, State, County, Regional, Tribal, City

- Type of order: Strategic

- Level of analysis: Systems, Organization

- What standard applies to: People, Process.

The NFPA 1561 Pros, Cons, and Conditions are shown in Table E.1. 
Table E.1 NFPA 1561 Pros, Cons, and Conditions

\begin{tabular}{|c|c|c|}
\hline Pros & Cons & Conditions for Adoption \\
\hline $\begin{array}{l}\text { Consistent with NIMS. } \\
\text { Broadly written and applicable } \\
\text { across disciplines. } \\
\text { Further defines implementation at } \\
\text { the local level. Provides roadmap } \\
\text { of how to get names to the local } \\
\text { level by } 2008 \text {. } \\
\text { Gets NIMS to the Federal, State, } \\
\text { and local level. } \\
\text { Standard is in place. }\end{array}$ & $\begin{array}{l}\text { There are states, municipalities, } \\
\text { counties that do not accept NFPA } \\
1561 \text {. } \\
\text { Single unit ambulance not really } \\
\text { ICS. (Function vs. form debate } \\
\text { that gets folks bogged down.) } \\
\text { Language written for fire } \\
\text { disciplines. } \\
\text { Might be substantively applicable } \\
\text { but that does not mean that it will } \\
\text { be politically acceptable. "It's a } \\
\text { fire thing." } \\
\text { Non-fire disciplines do not see a } \\
\text { fit. The biggest challenge is with } \\
\text { law enforcement. } \\
\text { There is not a neutral standards } \\
\text { development organization that is } \\
\text { "neutral" across disciplines. } \\
\text { Would need to make arrangements } \\
\text { to use the words of existing } \\
\text { standards developers. } \\
\text { Written for local governments. } \\
\text { Federal and States organizations } \\
\text { may not be in step with this. } \\
\text { (Example exceptions such as U.S. } \\
\text { Coast Guard and EPA.) }\end{array}$ & $\begin{array}{l}\text { Need to touch base with the } \\
\text { committee that is revising } 1561 . \\
\text { Ensure standard is conformable } \\
\text { with qualification and training } \\
\text { standards. } \\
\text { Consider implications (compliance } \\
\text { burdens) to State, County, regions, } \\
\text { and cities when adopting. } \\
\text { Needs to be more acceptable -- } \\
\text { take document, annotate it, and } \\
\text { apply it to NIMS. } \\
\text { Acceptability to States and other } \\
\text { (non-fire) disciplines. } \\
\text { Would need to be interdisciplinary. } \\
\text { Would need to come from neutral } \\
\text { organization (NIST may be a } \\
\text { neutral organization). } \\
\text { Joint standard process should be } \\
\text { used. } \\
\text { Endorse rather than enforce } \\
\text { standard if possible (as other } \\
\text { Federal agencies do such as DOJ). } \\
\text { NIC/DHS needs to step up to the } \\
\text { issues with interagency process } \\
\text { now (particularly with law } \\
\text { enforcement/DOJ). } \\
\text { Further vetting with broader State } \\
\text { and local representatives. } \\
\text { Federal government and States } \\
\text { need to be consistently } \\
\text { implementing NIMS along with } \\
\text { local jurisdictions. }\end{array}$ \\
\hline
\end{tabular}

\section{E.2 NFPA 1600: Standard on Disaster/Emergency Management and Business Continuity Programs}

\section{Panel Assessment:}

- NIMS Component/Subcomponent Supported:

- Command and Management

- Incident Command Structure

- Multi-agency Coordination Systems

- Public Information System

- Preparedness

- Planning

- Training 
- Exercises

- Personnel Qualification and Certification (program-level only)

- Mutual Aid

- Resource Management

- Communications and Information Management

- Incident Management Communications

- Information Management

- Ongoing Management and Maintenance

- Relevant Disciplines, based on Homeland Security Council definitions

- Emergency Management

- Government Administrators

- Level of government: Federal, State, County, Regional, Tribal, City

- Type of order: Strategic

- Level of analysis: Systems, Organization

- What standard applies to: Process.

NFPA 1600 Pros, Cons, and Conditions are shown in Table E.2.

Table E.2 NFPA 1600 Pros, Cons, and Conditions

\begin{tabular}{|c|c|c|}
\hline Pros & Cons & Conditions for Adoption \\
\hline $\begin{array}{l}\text { Used by the Emergency } \\
\text { Management Accreditation } \\
\text { Program (EMAP). } \\
\text { Adopted by the National } \\
\text { Emergency Management } \\
\text { Association (NEMA). } \\
\text { Widely endorsed by FEMA. } \\
\text { Standard is scalable. }\end{array}$ & $\begin{array}{l}\text { Acceptance issues with disciplines } \\
\text { other than fire. Many of the same } \\
\text { concerns as those expressed under } \\
\text { NFPA 1561, but to lesser extent. } \\
\text { May raise the need for jurisdictions to } \\
\text { confront new legislation (e.g., land } \\
\text { use and zoning) and associated } \\
\text { liability issues. Also requires } \\
\text { engagement of emergency } \\
\text { management in these areas. } \\
\text { Requires risk assessment, very } \\
\text { technical, most jurisdictions don't } \\
\text { have in-house capacity. } \\
\text { Also a private sector standard -- more } \\
\text { difficult to implement in the private } \\
\text { sector (e.g., utilities have done a lot, } \\
\text { but there is not necessarily a } \\
\text { relationship between the utilities and } \\
\text { local governments). } \\
\text { Emergency manager may not have } \\
\text { ability/capacity to implement. }\end{array}$ & $\begin{array}{l}\text { Requires a resilient (interagency, } \\
\text { regularly revised, tied to a training } \\
\text { and exercise program) planning } \\
\text { process. } \\
\text { Need to have stepped (phased) } \\
\text { approach for implementation and } \\
\text { compliance. } \\
\text { Resources sufficient to do capacity } \\
\text { building. } \\
\text { Implementation requires } \\
\text { cooperation between public and } \\
\text { private sectors. The onus is on the } \\
\text { public side to do this. May need } \\
\text { awareness and assistance. }\end{array}$ \\
\hline
\end{tabular}




\section{E.3 NFPA 472: Standard for Professional Competence of Responders to Hazardous Materials Incidents}

Panel Assessment:

- NIMS Component/Subcomponent:

- Preparedness (Training)

- Resource Management (Credentialing)

- Disciplines: All who have responsibility for HAZMAT response

- Fire Services

- Emergency Medical Service

- HAZMAT

- Law Enforcement - mission dependent

- Emergency Management - mission dependent

- Public Works

- Public Health - mission dependent

- Environmental

- Others: Urban Search and Rescue and Coroner/Medical Examiner

- Level of government: Federal, State, County, Regional, Tribal, City

- Type of order: Tactical

- Level of analysis: Sub-unit, Individual

- What standard applies to: People.

NFPA 472 Pros, Cons, and Conditions are shown in Table E.3.

Table E.3 NFPA 472 Pros, Cons, and Conditions

\begin{tabular}{|c|c|c|}
\hline Pros & Cons & Conditions for Adoption \\
\hline $\begin{array}{l}\text { Dictates the knowledge, skills and abilities of the } \\
\text { individuals to safely and effectively respond to } \\
\text { hazardous materials/WMD events. } \\
\text { Has multidisciplinary focus. } \\
\text { Well accepted by fire and hazardous materials } \\
\text { response teams and Federal law enforcement. } \\
\text { Has specific curricula associated with it. } \\
\text { In many States, already accepted/ accredited. } \\
\text { Good example of healthy standard that NIC } \\
\text { should adopt eventually. } \\
\text { This standard makes hazmat response protocols } \\
\text { more explicit than } 29 \text { CFR1910.120. } \\
\text { Standards like this one that pertain to basic } \\
\text { capacity can enhance the capabilities of the } \\
\text { community more than standards that cause them } \\
\text { to pursue specialized, narrow capabilities. }\end{array}$ & $\begin{array}{l}\text { Same acceptability barriers as noted } \\
\text { under other NFPA standards. } \\
\text { May be too specific for NIC (focuses } \\
\text { on tactical and individual level, not } \\
\text { system level). May result in future } \\
\text { burden to standards at this level. } \\
\text { Given the current NIMS/NIC } \\
\text { resources, this is not a priority. } \\
\text { Timing is not right for NIC/NIMS to } \\
\text { adopt because: } \\
\text { 1) Other efforts and working groups } \\
\text { (credentialing for example) work } \\
\text { should be allowed to mature to inform } \\
\text { the next decision. } \\
\text { 2) NIMS itself is not fully mature and } \\
\text { developed. }\end{array}$ & $\begin{array}{l}\text { System-level standards for NIMS } \\
\text { implementation should be in place } \\
\text { BEFORE this level of security and } \\
\text { detail are addressed. } \\
\text { Other efforts and working groups } \\
\text { (credentialing) work should be } \\
\text { allowed to mature to inform the } \\
\text { NIC's decisions. } \\
\text { NIC should clarify NIMS } \\
\text { credentialing responsibilities and } \\
\text { professional qualification. }\end{array}$ \\
\hline
\end{tabular}




\section{E.4 HEICS III (Hospital Emergency Incident Command System) (1992)/ASTM 2413-04}

Panel assessment:

- NIMS Component/Subcomponent Supported:

- Command and Management

- Preparedness

- Resource Management (capacity management)

- Ongoing Management and Maintenance (training and retraining)

- Relevant Disciplines:

- Emergency Medicine

- Health and Hospitals

- Others: Mental Health

- Level of government: Federal (e.g., Veterans Administration), State, County, Regional, Tribal, City, private hospitals, National Disaster Medical System

- Type of order: Strategic, with tactical aspects

- Level of analysis: Organization, Sub-unit (dictates a systems approach)

- What standard applies to: People, Process (i.e., a process affecting how people act).

HEICS III/ASTM 2413-04 Pros and Cons are shown in Table E.4.

Table E.4. HEICS III/ASTM 2413-04 Pros and Cons

\begin{tabular}{||l|l|l||}
\hline \multicolumn{1}{|c|}{ Pros } & \multicolumn{1}{|c|}{ Cons } & \multicolumn{1}{c|}{ Conditions for Adoption } \\
\hline \hline Potentially a good handle in \\
kicking off a response. \\
$\begin{array}{l}\text { Sets standards for position } \\
\text { location language. }\end{array}$ & $\begin{array}{l}\text { 9-1-1 has not been identified as a } \\
\text { responder. }\end{array}$ & $\begin{array}{l}\text { NIC should draw from this } \\
\text { document as needed. }\end{array}$ \\
& Has implications for terminology. & $\begin{array}{l}\text { Should the NIC be advocating for a } \\
\text { nation wide 9-1-1? }\end{array}$ \\
& $\begin{array}{l}\text { communication. } \\
\text { Doesn't address universal translator } \\
\text { mercator (UTM). Current NENA } \\
\text { system cannot communicate with } \\
\text { UTM. }\end{array}$ & $\begin{array}{l}\text { How do you track an incident } \\
\text { location? } \\
\text { Avoid guidelines as tools for } \\
\text { adoption. Focus on standards. May } \\
\text { choose to endorse guidance but not } \\
\text { considered adoption. }\end{array}$ \\
\hline
\end{tabular}

\section{E.5. NENA-01-002: Master Glossary of 9-1-1 Terminology}

The analysis framework was not completed for NENA-01-002 because the panel did not consider this to be a typical standard. 


\section{Appendix F}

Framework for Analysis of Standards 


\section{Appendix F}

\section{Framework for Analysis of Standards}

- NIMS Component/Subcomponent Supported

- Command and Management

- Incident Command Structure

- Multi-agency Coordination Systems

- Public Information System

- Preparedness

- Planning

- Training

- Exercises

- Personnel Qualification and Certification

- Equipment Acquisition and Certification

- Mutual Aid

- Publications Management

- Resource Management

- Communications and Information Management

- Incident Management Communications

- Information Management

- $\quad$ Supporting Technologies

- Ongoing Management and Maintenance

- Relevant Disciplines, based on Homeland Security Council definitions

- $\quad$ Fire Services

- Emergency Medical Service/Emergency Medicine

- Health and Hospitals

- HAZMAT

- Law Enforcement

- Public Safety Communications

- Emergency Management

- Public Works

- Public Health

- Government Administrators 
- Environmental

- Others

- Urban Search and Rescue

- Victim Support

- Mental Health

- Coroner/Medical Examiner

- Level of government

- Federal

- State

- County

- Regional

- Tribal

- City

- Type of order

- Strategic

- Tactical

- Level of analysis

- Systems

- Organization

- Sub-unit (e.g., department)

- Individual

- What standard applies to

- People

- Process

- Technology.

Note: Initially, "response level of complexity" was included in the framework. After working through several examples, it was determined that it was not a particularly useful criterion for analysis of standards. 


\section{Distribution}

No. of

\section{$\underline{\text { Copies }}$}

OFFSITE

3 Battelle Seattle Research Center

1100 Dexter Avenue N

Suite 400

Seattle, WA 98109-3598

ATTN: KS Judd

JL Kirk

S Stein

D Beyers

Washington State Department of Ecology

Ecology Spill Response

P.O. Box 47600

Olympia, WA 98504-7600

C Brannon

U.S. Department of Commerce/National Institute of Science and Technology

100 Bureau Drive, Stop 8460

Gaithersburg, MD 20899

LM Carpenter

Chief of Operations

Bainbridge Island Fire Department

8895 Madison Avenue

Bainbridge Island, WA 98110

41 Department of Homeland Security

Washington, DC 20528

ATTN: B Coursey

P Greenlaw

G Jamieson

P Mateson

B Rhodes

P Shebell (36)
No. of

Copies

E Dadosky

District Chief

Cincinnati Fire Department

2000 Radcliff Drive

Cincinnati, $\mathrm{OH} 45204$

A Donahue

Department of Public Policy

University of Connecticut

1800 Asylum Avenue, 4th floor

West Hartford, CT 06117

T Dunkle

Pennsylvania State University

Pennsylvania State Fire Academy

1150 Riverside Drive

Lewistown, PA 17044

2 Eastern Kentucky University

521 Lancaster Avenue

Richmond, KY 40475

ATTN: R Baggett

P Collins

B Gear

Benton County Fire Protection District \#1

11410 East Law Lane

Kennewick, WA 99337-2012

D Olsen

HAMMER Facility/RTII

2301 South Ledbetter Place

Kennewick, WA 99337

R Salter

Battelle Crystal City Office

1550 Crystal Drive Suite 601

Arlington, VA 22202-4172

Distr. 1 
No. of

Copies

B Sheldrake

Region 10

U.S. Environmental Protection Agency

1200 Sixth Avenue

Seattle, WA 98101

JR Stanton

Battelle Memorial Institute

505 King Avenue

Columbus, $\mathrm{OH} 43201$

G Suslavich

Science Applications International

Corporation

75 Valley Oak Drive

Somerset, KY 42503

D Trebisacci

National Fire Protection Association

1 Batterymarch Park

Quincy, MA 02169-7471

W Yoder

Training Specialist

Hazardous Materials Program

Fire Administration/National

Fire Programs

Response Section FEMA, DHS

16825 S. Seton Avenue

Emmitsburg, MD 21727
No. of

Copies

61 Pacific Northwest National Laboratory

D Creighton K7-50

GM Gelston K6-52

M Hevland K7-98

S Martin K8-21

M Mitchell K8-60

DS Schwartz K6-52

K Soldat K3-53

RD Stenner (50) K3-54

K Thrall P7-59

N Wogman K8-29

Information Release (2) P8-55 